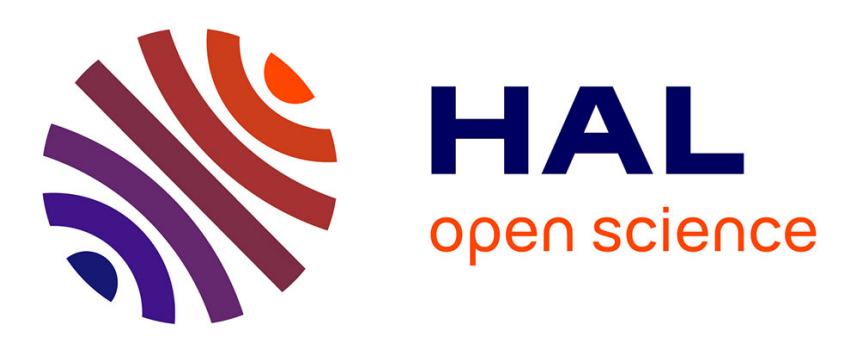

\title{
High-Resolution Sedimentary Budget Quantification - Example from the Cenozoic Deposits in the Pelotas Basin, South Atlantic
}

\author{
S. Rohais, J.-P. Lovecchio, V. Abreu, M. Miguez, S. Paulin
}

\section{- To cite this version:}

S. Rohais, J.-P. Lovecchio, V. Abreu, M. Miguez, S. Paulin. High-Resolution Sedimentary Budget Quantification - Example from the Cenozoic Deposits in the Pelotas Basin, South Atlantic. Basin Research, 2021, 33 (4), pp.2252 - 2280. 10.1111/bre.12556 . hal-03353552

HAL Id: hal-03353552

https://hal-ifp.archives-ouvertes.fr/hal-03353552

Submitted on 24 Sep 2021

HAL is a multi-disciplinary open access archive for the deposit and dissemination of scientific research documents, whether they are published or not. The documents may come from teaching and research institutions in France or abroad, or from public or private research centers.
L'archive ouverte pluridisciplinaire HAL, est destinée au dépôt et à la diffusion de documents scientifiques de niveau recherche, publiés ou non, émanant des établissements d'enseignement et de recherche français ou étrangers, des laboratoires publics ou privés. 
DR SÉBASTIEN ROHAIS (Orcid ID : 0000-0002-0659-4714)

Article type : Research Article

\section{HIGH-RESOLUTION SEDIMENTARY BUDGET QUANTIFICATION - EXAMPLE FROM THE CENOZOIC DEPOSITS IN THE PELOTAS BASIN, SOUTH ATLANTIC.}

S. ROHAIS 1*, J.P. LOVECCHIO 2, V. ABREU 3, M. MIGUEZ 4, S. PAULIN 5

1 IFP Energies nouvelles, 1 et 4 avenue de Bois-Préau, 92852 Rueil-Malmaison, France (sebastien.rohais@ifpen.fr)

2 YPF S.A. Exploration. Macacha Güemes 515, 1106, Buenos Aires, Argentina

3 Abreu Consulting and Training (ACT-GEO), 344 W 22nd St., Houston, TX 77008, US

4 Pampa Energía - Maipú 1, Capital Federal - Buenos Aires, Argentina

5 TOTAL E\&P, CSTJF - Avenue Larribau, 64018 Pau Cedex, France

\section{ABSTRACT}

In this paper, we propose a high-resolution (HR) sedimentary budget quantification at basin-scale for the Cenozoic deposits of the Pelotas Basin (South Atlantic). A new workflow is implemented including five main steps: (i) basin-scale analysis and characterization, (ii) quality control and selection of reference 2D dip-sections, (iii) HR seismic stratigraphy analysis, (iv) sediment supply estimation taking into account This article has been accepted for publication and undergone full peer review but has not been through the copyediting, typesetting, pagination and proofreading process, which may lead to differences between this version and the Version of Record. Please cite this article as doi: $\underline{10.1111 / B R E .12556}$

This article is protected by copyright. All rights reserved 
lithology and porosity corrections and then $(v)$ the estimation of the sedimentary budget curve including 41 time-intervals for the last 65 Myr. Variance ranges were determined considering the parameters of the method on the case study. The main uncertainties are related to the seismic velocities for the time-todepth conversion (5-22\%), the method for lithological parameters quantification and associated porosity correction (4.4-14.3\%), the absolute ages of stratigraphic markers (1-25\%), and the proportion of in-situ sediment production (0.3-0.5\%).

For the very first time, this method allows the identification of several cycles from an entire sedimentary basin fill characterized by pulses of sediment supply (Qs) whose growth phase lasts less than 1 Myr, followed by a constant phase lasting 1-2 Myr, and finally an exponentially decreasing phase lasting 2-5 Myr. These pulses alternate with phases where the sediment supply was very low for intervals of ca. 1-5 Myr. Ten major pulses were recognized during the Cenozoic. We propose that the sediment supply dynamic in the Pelotas basin records the orogenic phases of the Andes located more than 2,000 km upstream. The recorded Qs pulses in the basin are out of phase with respect to the active tectonic phases of the Central Andes. Finally, by comparing the volume of preserved sediment and the production capacity of the catchment, we suggest that a source of sediment in addition to the Brazilian craton and the Andes should be envisaged, potentially associated with deep-water oceanic circulation.

\section{INTRODUCTION}

Patterns of sediment supply (Qs) in time and space record the complex interplay of tectonism, climate change, and drainage basin evolution (e.g. Schumm \& Rea, 1995; Galloway et al., 2011). The estimation of Qs is the key for source-to-sink (S2S) studies, i.e. the quantity of solid matter that will be transported from the eroding area in the catchment (Source), through the transfer area, towards the final depositional area in the sedimentary basin (Sink). To understand the variations in relief, the Qs is analyzed either through sedimentary budgets in the associated basins (Rust \& Summerfield, 1990; Pazzaglia \& Gardner, 1994; Pazzaglia \& Brandon, 1996; Jones et al., 2002; Walford \& White, 2005; Rouby et al., 2009; Guillocheau et al., 2012; Rohais et al., 2016; 2019; Rohais \& Rouby, 2020), or using as an analog the sediment load of modern rivers (Milliman \& Syvitski 1992; Hovius, 1998; Syvitski \& Milliman, 2007; Zhang et al., 2018). The estimated Qs is then compared to other methods for estimating the rates of denudation and / or erosion in the catchment areas (e.g. Gallagher et al., 1998; Calvès et al., 2012). Qs is also a central element in the 
interpretation of the stratigraphic architecture since it is one of the factors controlling the type of depositional environment (e.g. wave / fluvial / tide-dominated deltas) (Galloway, 1975) and because its intrinsic variations can also mimic stratigraphic responses that may initially be interpreted to be only eustatically driven (Zhang et al., 2019).

Amongst all the recent studies on S2S analysis, one of the main challenging issues is to be able to extrapolate the concepts based on modern analogs to ancient systems. Such challenges involve testing the application of the S2S methodology to deep time (Bhattacharya et al., 2016), applying concepts and models established on present-day systems (i.e., Holocene) to larger time scales (0.01, 0.1 up to $100 \mathrm{Myr}$ ). This should ultimately allow the link on all time scales between the controlling factors and their record in sedimentary basins (Fig. 1). It is also crucial to discuss the response times of the systems (e.g. Castelltort \& Van den Driessche, 2003), since it is not the amplitude of the Qs pulse that will have interest at first, but rather the shape of the sediment supply curve (e.g. Schumm \& Rea, 1995; Bonnet \& Crave, 2003; Rohais et al., 2012).

Metivier et al. (1999) proposed estimates of mass accumulation rates in eighteen offshore sedimentary basins in Asia since the beginning of the Cenozoic for nine time-steps. Galloway et al. (2000) established paleogeographic and volumetric lithofacies mapping of 18 genetic sequences within the Northern Gulf of Mexico basin to quantify the sediment supply during the Cenozoic. This work has been refined for the coastal area (Galloway, 2001) and integrated in a complete S2S study to discuss the forcing parameters on Qs dynamics (Galloway et al., 2011). Rouby et al. (2009) reviewed published data to quantify the terrigenous supply eroded from the South African plateau to the Orange sedimentary system over the last 150 Myr using 3 to 5 time-intervals. Guillocheau et al. (2012) studied in more detail the same case using 10 time-intervals. The range of time steps explored in these studies is from ca. 3.6 Myr (Galloway et al., 2000) to 50 Myr (Rouby et al., 2009), with a mean common value of ca. 8-10 Myr. More recently, Rohais \& Rouby (2020) proposed paleogeographic and volumetric lithofacies mapping of 26 depositional units for the Miocene deposit of the Suez rift, that is a mean time step of ca. 0.9 Myr. Rohais et al. (2019) also proposed a high-resolution study of the Late Cretaceous-Early Cenozoic lacustrine deposits of the Salta rift basin (Argentina) with a mean time step of ca. 0.2 Myr for a 5 Myr duration interval. Such high-resolution is desired to bridge the gap between forcing mechanisms and resulting sedimentary signal (Fig. 1). Effectively, when dealing with periods of climate or tectonic forcing of 50-100 kyr, the resulting Qs signal can be buffered by a long transfer zone (e.g., Castelltort \& Van Den Driessche, 2003), or by catchment dynamics (Armitage et al., 2013), or oppositely amplified either by river transport processes (Simpson \& Castelltort, 2012), or catchment dynamics (Godard et al., 2013). To address and solve these issues, it is 
necessary to establish sedimentary budgets at high resolution (e.g. with time steps of ca. 1 Myr or even lower when dealing with basin fills of tens of Myr) to be able to discuss the signal propagation from S2S, and especially at intermediate timescales (0.1 - $10 \mathrm{Myr}$, Fig. 1). This assumes that exogenic signals in the source area will faithfully be transmitted and preserved in the sink area. Indeed, as the temporal resolution in the sink improves, forcing mechanisms in the source area will increasingly overlap with signals generated by autogenic as well as stochastic processes.

It is relatively easy to estimate a sedimentary budget, but its use in S2S studies is limited over long-lasting time steps (e.g. Metivier et al., 1999; Galloway et al., 2010; Guillocheau et al., 2012), potentially completely smoothing the climatic and tectonic signals (Fig. 1) or making them indistinguishable. To be able to extrapolate HR timelines across an entire basin, there are two main challenges to deal with: the quality and availability of data and the age extrapolation. Regional seismic data are very often the way to restore the geometry of a basin. It is also possible to restore basin geometry using outcrops, but it is necessary to have representative 3D exposures distributed along the basin, which is very uncommon, or 2D sections across the entire basin and local, smaller 3D outcrops. Well data, when available, is used to calibrate seismic interpretation, by helping to adjust time-to-depth conversion, and to assign absolute ages to the seismic sequences. Considering the various methods for integrating absolute ages to sedimentary deposits (Fig. 1), sequence stratigraphy seems to be the best one to interpolate between calibration points (wells), predicting lithology distribution and defining the 3D architecture and age relationships of different sedimentary packages. Therefore, seismic and sequence stratigraphy are essential tools to deal with high-resolution quantification of sediment budgets (Fig. 1). However, even if extensive 3D seismic data is available (e.g. Paumard et al., 2019 a, b), the entire sedimentary basin is rarely fully-covered, especially the ultra-distal part beyond the turbidite lobes, which usually remains underexplored. 2D methods for quantifying sediment supply had already been developed and tested against 3D volumes estimation in the Washakie basin (Petter et al., 2013) and applied to the Orinoco margin (Chen et al., 2017). The method proposed by Guillocheau et al. (2012) is also a major insight into the study of entire sedimentary basins using sparse and heterogeneous datasets.

This contribution proposes a workflow based on reasonable amounts of data to be used as a guide to similar studies in other basins. We have chosen to work on the Cenozoic strata of the Pelotas basin (Fig. 2), where the seismic coverage and the age constraints are very good, and a well-established HR seismic sequence stratigraphic framework is also available (Fontana, 1996; Abreu, 1998; Abreu et al., 2010; Contreras et al., 2010; Conti et al., 2017; Morales et al., 2017). Therefore, a high-resolution study is feasible with 41 time-intervals within the Cenozoic, corresponding to a time step of ca. 1.6 Myr. 
Hereafter, we present (i) the database used in the establishment of the 3D geometry of the Pelotas basin, (ii) the quantification of the solid volumes of siliciclastic sediments preserved in the basin, and finally (iii) discuss the potential controlling factors on the Qs dynamic in the Pelotas basin during the Cenozoic.

\section{CASE STUDY: THE PELOTAS BASIN}

The Pelotas Basin is located offshore SE Brazil and Uruguay between $28^{\circ} 40^{\prime} \mathrm{S}$ and $34^{\circ} \mathrm{S}$ (Figs. 2 and 3). The basin is limited by the Florianopolis High (Brazil) to the north and the Polonio Arch (Uruguay) to the south (Kowsmann et al., 1982; Bassetto et al., 2000). An onshore segment of approximately $40,000 \mathrm{~km}^{2}$ covers the near shore area of Santa Catarina and Rio Grande do Sul states in the Brazilian segment (Fig. 3). The Torres Arch (TA in Fig. 3) is also a major tectonic feature across the Pelotas basin.

This part of the western South Atlantic margin has received wide attention in recent years, on a large diversity of topics as margin structure and development (e.g. Jackson et al., 2000; Mohriak et al., 2002; Franke et al., 2007, 2010; Blaich et al., 2009; Soto et al., 2011; Stica et al., 2014; Lovecchio et al., 2020), erosional and depositional products of contour currents (e.g. Hernández-Molina et al., 2009, 2010, 2016; Creaser et al., 2017), sediment dynamics and slope stability (e.g. Krastel et al., 2011), source rock maturity (Grassman et al., 2011), subsidence analysis (e.g. Contreras et al., 2010), and petroleum potential (e.g. Fontana, 1989; Saunders \& Bowman, 2014; Conti et al., 2017, Morales et al., 2020).

The Pelotas basin formed as a result of the break-up of Gondwana and the opening of the South Atlantic Ocean during the Early Cretaceous, related to the last event of a multi-stage extensional history of this continental margin (Lovecchio et al., 2018, 2020). The post-breakup Cretaceous and Cenozoic successions were deposited in a passive margin setting during the drift phase. The maximum sedimentary column, including Aptian-to-Holocene strata, is about $12 \mathrm{~km}$-thick in the central part of the Pelotas basin (Fontana, 1996), in the region defined as the Rio Grande Cone (RGC, Fig. 3).

The sedimentary record in the Pelotas continental margin consists of four stratigraphic successions (Dias et al., 1994; Fontana, 1996; Abreu, 1998; Bueno et al., 2007; Contreras et al., 2010; Soto et al., 2011; Morales et al., 2017): (1) the pre-rift, corresponding to Paleozoic-Early Mesozoic non-marine and marine sediments of the Paraná basin preserved at the base of some half-grabens and on tilted-blocks, (2) the syn-rift, formed by Early Cretaceous volcanic successions (primarily Seaward Dipping Reflectors - SDRs, Fontana, 1987, 1996; Talwani \& Abreu, 2000; Stica et al., 2014) and non-marine sediments, (3) a transitional phase (i.e. early post-breakup), that corresponds to Barremian-Aptian non-marine to marine 
sediments, and (4) the drift phase, composed of Late Cretaceous and Cenozoic marine sediments. Paleobathymetric reconstructions suggest that the deepest part of the Pelotas basin was already at 1,000 $\mathrm{m}$ water-depth during the Aptian and might have reached up to 4,000 m water-depth during the latest Cretaceous (Pérez-Diaz \& Eagles, 2017).

The catchment area of the Pelotas basin developed onshore to the west, consists of two main domains: (1) to the south the littoral catchment feeding the present-day Mirin and Patos lagoons $\left(28,955 \mathrm{~km}^{2}\right)$, and (2) to the north the Guaíba catchment $\left(8,480 \mathrm{~km}^{2}\right.$, Fig. 3). Additionally, sediment supply passing through the Río de la Plata estuary from the Paraná and Uruguay rivers were fed to the north to form the Rio Grande Cone, developed $400 \mathrm{~km}$ to the NE of the Rio de la Plata estuary (Castillo \& Chemale, 2014, Figs. 2 and 3). These river systems drain very large catchment areas $\left(2,600,000 \mathrm{~km}^{2}\right)$, initiating in the Andes and crossing the entire South American continent (Fig. 2). The present-day Río de la Plata system is considered a tropical river basin, with approximately $50 \%$ of the drainage area in a dry and wet tropical climate (Henry et al, 1996). The annual water discharge of $470 \mathrm{~km}^{3}$ (Milliman \& Meade, 1983) is supplied by the Paraná River and its tributaries and by the Uruguay River (Depetris \& Griffin, 1968), corresponding to $75 \%$ and $25 \%$ of the total discharge, respectively. The Rio de la Plata estuary is in its present-day configuration since at least the Late Cretaceous (e.g. Pérez-Díaz \& Eagles, 2017; Lovecchio et al., 2020). The dynamic of the catchment area of the Parana river is poorly constrained for the Cenozoic.

Paleo-oceanic circulation during the Cretaceous was markedly different than today's circulation due to major differences in land-mass distribution and paleobathymetry (Pérez-Díaz \& Eagles, 2017). The first evidence of a weak proto-Antarctic Circumpolar Current (ACC) was simulated for the Albian (UenzelmannNeben et al., 2017). This stage was characterized by a much lower temperature gradient between the poles and the equator. The deep-water deposits of the Pelotas basin were dominated by bottom-current flows to the north during the Late Cretaceous (Creaser et al., 2017). No change in circulation was observed until the Paleocene/early Eocene South Atlantic (Hernández-Molina et al., 2016; UenzelmannNeben et al., 2017). The most drastic changes were documented for the Eocene/Oligocene boundary and the Oligocene/early Miocene with the onset of the ACC and the Atlantic meridional overturning circulation (AMOC), with a southern-sourced deep and bottom water masses in the western South Atlantic (Hernández-Molina et al., 2009). A modern AMOC, which intensified in strength after closure of the Central American Seaway (CAS), and a strong ACC have resulted in current-controlled sedimentary features (e.g. plastered drifts) and widespread hiatuses in the South Atlantic since the middle Miocene (Hernández-Molina et al., 2016; Uenzelmann-Neben et al., 2017). Tectonic processes such as the opening of Drake Passage in Eocene times (deepest part opening at 28-31 Ma) and the closure of the CAS at ca. 6

This article is protected by copyright. All rights reserved 
Ma have been identified as the key triggers for the most significant changes in oceanic circulation observed in the South Atlantic (Uenzelmann-Neben et al., 2017). To the northeast of the Pelotas basin, the main present-day deep-water sediment paths are related to the Brazilian Current (BC) and to the North Atlantic Deep Water (NADW, Fig. 2), while to the southwest, the Antarctic Bottom Water (AABW) acts as a deep-water sediment carrier towards the Pelotas basin (Fig. 2)

\section{DATASET AND METHOD}

The dataset for the present study included 69 seismic lines and 8 wells (Fig. 3, Table 1). Most of the wells are located on the shelf, except for the well DSDP Site 356 (Perch-Nielsen et al., 1977) that provided good constrains on the deepest part of the basin (Fig. 3). We focused on the Cenozoic deposits as the age constraints are good enough to implement our workflow.

The method established hereafter aims to deliver HR sediment supply from the stratigraphic architecture of a sedimentary basin infill (Fig. 4).

The first step (1 in Fig. 4) corresponds to basin-scale characterization. It considers the establishment of: a) the stratigraphic architecture (Fig. 5), b) the correlation of the internal architecture across the basin (Fig. 6), and c) the establishment of an age model (Table 2). Mapped depositional units corresponds to architectural building blocks of the basin fill (i.e. depositional units of 5-10's Myr for a basin fill of 10's to 100 's Myr). The main deliverables are sedimentary unit volumes for established stratigraphic/time intervals (Fig. 6). Location maps of wells and seismic lines were initially prepared with QGIS Geographic Information System (Open Source Geospatial Foundation Project, http://qgis.org). Seismic interpretation and 3D volume calculation were carried out using GOCAD ${ }^{\circledR}$ (https://www.pdgm.com/products/gocad/) to generate thickness maps. Ten thickness maps were then prepared for the Cenozoic, and one for the Cretaceous (Fig. 6). Similar workflows had already been proposed by the pioneer work of Poag \& Sevon (1989), Galloway (2001) and later by Guillocheau et al. (2012) and Rohais et al. (2016).

A second step involves quality control of the data assembled in Step 1 (2 in Fig. 4). We introduce the Representative Proportion Curve (RPC) to select a 2D basin-scale dip cross-section for HR sequence stratigraphic studies. The relative proportion of each interval is computed along the selected 2D sections and then compared to the relative proportion of the interpreted 3D volumes on the entire basin. The relative proportion of the interpreted 3D volumes on the entire basin is computed for the ten investigated depositional units. For example, the Plio-Quaternary deposits ( $X$ in Fig. 6) account for 14\% of the total 3D 
basin fill volume (Table 3). The relative proportion of each of the ten intervals is also computed in 2D along selected dip cross-sections and then compared to the relative proportion derived from the 3D volume (Table 3). The ratio between these proportions (2D versus 3D) corresponds to the Correction Factor (CF) computed for each depositional unit. A CF can be based on a seismic line either in True Vertical Depth (TVD) or Two Way Time (TWT), taking into account the time-to-depth conversion. The best representative cross-section is selected based on low Correction Factors (i.e., close to 1 ) for each interval, and well-constrained HR age model (i.e., well at or near the seismic section). For example, CF value of 0.91 was applied to the seismic section 0228-0327 (Fig. 7) for the high-resolution interpretation of the PlioQuaternary section, in order to keep the large-scale consistency of the dataset (Fig. 8, Table 3). We compute the RPC and CF for four dip sections (Fig. 5) in order to select the most representative dip section for the Pelotas basin (Table 3).

The third step is to perform a HR seismic stratigraphic analysis in dip seismic sections showing entire basin fills in 2D, or multi-2D (3 in Fig. 4). Regional, high-resolution, sequence stratigraphy is established using the basic seismic stratigraphy techniques outlined by Vail et al. (1977) and updated and expanded by Vail (1987), Haq et al. (1987) and Van Wagoner et al. (1988). Seismic line 0228-0327 (Section 1 in Fig. 5) was selected to carry out a HR sequence stratigraphic study (Fig. 7), as the trend and value identified for the RPC are consistent with the RPC computed for the large-scale seismic units (Fig. 8a and b). We refer to the work of Abreu (1998) and Abreu et al. (2010) that already provided HR seismic interpretation on this same section. It provides 41 stratigraphic intervals that we used to compute the RPC at high resolution (RPC-HR, Fig. 8). The age model and well-seismic tie are also derived from Abreu (1998), as well as the recent contributions of Rosa et al. (2017). In the southern part of the basin, close to the Punta del Este Basin, the work of Pérez Panera et al. (2016) was used to review the interpretation of Conti et al. (2017) and Morales et al. (2017). The CF previously computed for seismic line 0228-0327 were then used to establish the RPCHR on the section 1 for the following steps (Fig. 8). The RPC-HR shows the relative volumetric importance of the Paleocene (I), Lower Eocene (II), and Mid- to Upper Eocene (III) as each of them account for $6-8 \%$ of the total volume of preserved sediment in the Pelotas basin (Fig. 8). Several pulses are documented from Oligocene to recent, with a maximum at around $14 \mathrm{Ma}$ (close to Ser-1 sequence boundary, Hardenbol et al., 1998) accounting for $10 \%$ of the total volume of sediment (Fig. 8).

The fourth step is to estimate sediment supply (Qs) (4 in Fig. 4), discriminating sediment fluxes entering the basin from catchment erosion and weathering, as well as in-situ sediment production. We refer to previous workflows proposed by Rohais et al. (2016) and Rohais \& Rouby (2020), who used paleogeographic and lithological maps to calculate the relative proportion of the dominant lithology to 
finally estimate the detrital versus in-situ sediment production (e.g. carbonate, evaporite). In the present study, as few paleogeographic maps are available, we have used the chronostratigraphic chart of Bueno et al. (2007) and the available well data to estimate the relative proportion of the dominant sediment for each depositional unit: sand, silt, clay and carbonate mud (Table 4, Fig. 9). The volumes of each sediment type were finally corrected from remaining porosity using the method of Poag \& Sevon (1989).

The fifth step is the final HR sedimentary budget estimation (5 in Fig. 4), combining the large-scale depositional units (volumes) with the 2D RPC computed at high resolution (RPC-HR, Fig. 9g), and correcting age model uncertainties (Fig. 10).

\section{RESULTS}

\section{Large-scale stratigraphic architecture}

Considering the pioneer works of Fontana (1996) and Abreu (1998) and the most recent publications (Contreras et al., 2010; Rosa et al., 2017; Conti et al., 2017; Morales et al., 2019), the Cenozoic deposits of the Pelotas Basin were divided in ten main seismic depositional units (Fig. 5). The age model is derived from the work of Abreu (1998) that results from a detailed seismic sequence stratigraphic study on seismic profile 0223-0327 (section 1 in Fig. 5) and well P4 (1-SCS-0002-SC), where $80^{18}$ was used to constrain the age of each seismic reflection. The mean duration of sequences was determined based on biostratigraphy together with a correlation with oxygen isotope curves (Abreu, 1998).

The Paleogene succession is composed of five seismic stratigraphic units (I to V in Fig. 5): (I) Paleocene, (II) Lower Eocene, (III) Mid-to-Upper Eocene, (IV) Lower Oligocene and (V) Upper Oligocene. The Neogene succession is composed of five seismic stratigraphic units (VI to X in Fig. 5): (VI) Lower Miocene, (VII) Middle Miocene, (VIII) Upper Miocene, (IX) uppermost Miocene and (X) Plio-Quaternary. These ten main seismic units where subdivided into 41 seismic sub-units derived from Abreu (1998) and, updated with the interpretations of Rosa et al. (2017), to assess the Cenozoic strata at higher resolution (Table 2). We have followed these interpretations as they are a reference for seismic stratigraphy concepts and training (e.g. Abreu et al., 2010). Figure 6 shows the isopach maps for depositional units of the Paleocene to PlioQuaternary series resulting from the proposed basin-scale characterization (step 1 in Figure 4). The Cretaceous isopach map is also presented to show the sedimentary depocenters previous to the Cenozoic. During the Cretaceous, the main depocenters were localized along the Polonio and Torres arches (Fig. 6). 
In the most distal part of the basin, the isopach map shows a set of large domal features, compatible with deep-water drift systems.

The Paleogene is primarily organized in aggradational packages, while the Oligocene marked a turn towards a progradational stacking pattern that characterizes the Neogene (Fig. 5).

Paleocene (I): This unit often shows onlap terminations on top of the Cretaceous deposits (Fig. 7). The Paleocene package is locally truncated in the vicinity of the Torres and Florianopolis Arches (Middle Eocene erosional event). The isopach map of this unit shows a main depocenter in the Rio Grande Cone area, with a thickness greater than 1,500 meters (Fig. 6-I). Based on seismic data, the main provenance for sediments is interpreted to be from the Torres Arch located in the northern part of the basin.

Lower Eocene (II): This package is very thin, and locally not preserved in the proximal part of the basin (NW) and in the vicinity of the Torres and Florianopolis Arches (Fig. 6-II). The main depocenter of this unit is in the Rio Grande Cone area and in the plunge of the Polonio Arch (Fig. 6-II). Sediments of this age are also present in the deepest southeastern part of the basin (contourite deposits?).

Middle to Upper Eocene (III): The Middle Eocene unit has a depocenter (> 2,000m-thick) in the northeastern part of the Rio Grande Cone area and progressively onlaps the Torres Arch (Fig. 6-III). The main provenance area remained the northern part of the basin. Large and relatively thick depocenters (> 500 m-thick) are present in the most distal part of the basin.

Lower Oligocene (IV): contrary to the older units, the main depocenter of this package is in the deepest (eastern) part of the basin (>1,000 m-thick). Sediment supply seems to be line-sourced, as a single entrypoint could not be determined (Fig. 6-IV). Therefore, sediment source feeding the Rio Grande Cone area from the north in older units is not as relevant for this stage.

Upper Oligocene (V): This unit is laterally stacked compared to the Lower Oligocene unit, but displays a similar trend, with a depocenter in the deepest part of the basin (Fig. 6-V), often showing localized seismic mounding in deep-water (fans and/or contourite drifts).

Lower Miocene (VI): The main depocenter (>2,000 m-thick) is present in the northeastern part of the basin (deep-water) (Fig. 6-VI). Seismic geometries observed in this depocenter and along the base of the slope are similar to the ones identified in the Oligocene package, including lateral compensation.

Middle Miocene (VII): this unit displays the same trend as the Lower Miocene (Fig. 6-VII), but not as thick (>1,500 m-thick) and more widely spread.

This article is protected by copyright. All rights reserved 
Upper Miocene (VIII): this unit presents a large depocenter (> 2,000 m-thick) localized in a slope setting in the Rio Grande Cone area (Fig. 6-VIII). A 500 m-thick depocenter also occurs in the deepest part of the basin in the vicinity of the Pelotas and Rio Grande drifts area.

Uppermost Miocene (IX): this unit is thinner (ca. 1,000 m-thick) but displays a similar geometry as the Upper Miocene unit (Fig. 6-IX).

Plio-Quaternary $(\mathrm{X})$ : this unit is also similar in trend to the Upper Miocene unit (Fig. 6-X) but displays larger thickness (> 3,000 m-thick). The Rio Grande Cone is well defined along the basin slope, showing a mounded geometry from the shelf to the deep-water area (>3,000 m-deep, Fig. 5).

The comparative analysis of these maps highlights the importance of the intra-basinal Torres Arch in the paleogeography of the Pelotas Basin. A change in the sediment dispersion pattern since the Upper Eocene can be observed in these maps (III in Fig. 6), when sediment sources towards the basin predominated (relatively orthogonal to the present-day slope) in detriment of the supply directly from the Torres Arch towards the south (Rio Grande Cone depression). The Paleocene to Eocene units are characterized by the development of a starved basin floor with one main depocenter along the margin-slope. There is a marked change in sedimentation during the Oligocene, with a shift in depocenters towards the deepest part of the basin, suggesting a strong deep-water sedimentation at that time. The Early Miocene recorded major supply from the NE of the Pelotas basin, potentially sourced from the Santos Basin located north of the Florianopolis High. From the Middle Miocene to the Plio-Quaternary, the main depocenters progressively migrated from NE to W-SW (Fig. 6).

\section{High resolution sediment supply for the Cenozoic deposits}

The mean sediment supply (Qs) estimated for the Pelotas basin during the Cenozoic is of 49,554 km³/Myr. Ten main Qs pulses (1-10) can be identified as local maxima displaying a very consistent shape, characterized by a sharp and rapid increase up to a maximum followed by a progressive, less abrupt decrease (Fig. 9g).

At the end of the Eocene and up to the Middle Oligocene, Pulses 1, 2 and 3 are organized in an overall increase of their maximum value, ca. 41,000; 121,000 and 247,000 km³/Myr respectively (Fig. 9g). These three pulses are about 4-6 Myr of duration and mark the first clear pulses following a 28 Myr-long period (Paleogene) characterized by very low sediment supply, ranging from 26,000 to $30,000 \mathrm{~km}^{3} / \mathrm{Myr}$ (half of 
the mean value of the Cenozoic). Age resolution during this time is quite limited, with a small number of markers.

Just after pulse 3 (ca. 27-23 Ma), the sediment supply was very low (Fig. 9g), with about $10 \%$ of the mean value for the Cenozoic (ca. 5,000 km³/Myr). This period corresponds to a large portion of the Upper Oligocene.

At the base of the Miocene (Fig. 9g), Pulse 4 was organized as the previous ones, with similar duration and amplitude (ca. 142,000 km³/Myr). Similarly to Pulse 3, Pulse 4 is followed by a 4-5 Myr-long period (ca. 19$14 \mathrm{Ma}$ ) of very low sediment supply (ca. 6,500-14,000 km³/Myr).

Pulse 5 (ca. 14-10 Ma in the Middle Miocene) was the most important sedimentary pulse of the Cenozoic, about 15 times larger than the average value for the era (of ca. $800,000 \mathrm{~km}^{3} / \mathrm{Myr}$ ). The Qs decrease is very rapid, in less than 4 Myr (Fig. 9g).

Pulse 6 lasted for ca. 3 Myr with a maximum of about 66,000 km³/Myr (Fig. 9g) during the Upper Miocene.

During the uppermost Miocene, Pulse 7 lasted for ca. 4 Myr (Fig. 9g) and is characterized by a longer plateau with a maximum Qs value of ca. 105,000 km³/Myr. It is followed by a 1 Myr-long period (ca. 4.53.5 Ma) with very low sedimentation rate (ca. 8,000 $\mathrm{km}^{3} / \mathrm{Myr}$ ).

During the Plio-Quaternary, Pulses 8, 9 and 10 had shorter duration (cycles of 0.3-0.5 Myr) than the previous ones. Pulses 9 and 10 have maximum Qs values about 5 times higher than the mean Cenozoic rates, with 262,000 and 225,000 km³/Myr respectively (Fig. 9g).

\section{Source of uncertainties for Qs estimation}

According to Guillocheau et al. (2012), the main sources of uncertainties for sedimentary budget estimation are (i) the method for 3D geometrical extrapolation especially in poorly constrained areas, (ii) the uncertainties on seismic velocities in time-to-depth conversion, (iii) the absolute ages of the interpreted markers and horizons and (iv) the sediment type and porosity estimation. Given that the studied area is extensively covered by 2D seismic data (Fig. 3) the influence of the extrapolation method was not crucial in this case.

This article is protected by copyright. All rights reserved 


\section{Seismic Velocities Uncertainty}

Time-depth conversion performed in this work assumed a homogeneous interval velocity in the ten investigated time-intervals (Table 4). The time-to-depth conversion is based on the seismic well-tie of the four wells studied by Abreu (1998) (Table 2), which is consistent with previous studies (Fontana 1996; Contreras et al., 2010). To quantify the influence of seismic velocities on the 3D budget estimation, minimum and maximum values were investigated for each studied interval (Fig. 10a, Table 4).

The mean associated variance ranges between $5 \%$ to $22 \%$ of the preserved sediments volumes (Fig. 10), reaching locally up to $60 \%$ in the Paleogene (Fig. 10). The time-to-depth conversion is poorly constrained for the basal part of the Cenozoic strata. The investigated volumes are also relatively low, increasing the uncertainty related to seismic velocities for these units.

\section{Age Model Uncertainty}

Our starting point was the age model presented by Abreu (1998) (Table 2). It was based on biostratigraphy using nannofossils, the comparison of a composite smoother $\delta^{18} \mathrm{O}$ record for the Cenozoic, using isotope events identified in DSDP/ODP and well P4, oxygen isotope records compared with the sequence boundaries of Hardenbol et al. (1998), the eustatic curves of Haq et al. (1987) and the time scale presented by Berggren et al. (1995) used as reference.

The available models were recently integrated and updated by Rosa et al. (2017). In this work, absolute ages were updated and re-calibrated for the stratigraphic surfaces bounding the 41 units, using the ICS stratigraphic chart of Gradstein et al. (2012). Table 2 presents the three different age models. The resulting sediment supply curves based on these age models are presented in Figure 10b.

There are two main differences in these age models, particularly for the Upper Oligocene (V) and the Lower Miocene (VI) (Table 2). The stratigraphic surfaces impacted by major changes are Ru-3 (surface 19, that changed from 31.5 to $29.18 \mathrm{Ma}$ ), Aq-1 (surface 22, changed from 27 to $23.03 \mathrm{Ma}$ ), and Bur-1 (surface 23 , changed from 23.8 to $20.43 \mathrm{Ma}$ ).

Using either the age model of Abreu (1998) or Rosa et al. (2017), there is a shift of the sediment supply curves for the Lower Miocene. The identified pulses 3 and 4 are strongly shifted (Fig. 10b). Remaining trends are very similar using the three different age models. The mean associated variance referring to 
the age model of Abreu (1998) or Rosa et al. (2017), ranges from $1 \%$ to $25 \%$ of the volumes of preserved sediments (Fig. 10b).

\section{Sediment type (carbonate mud correction) and Porosity}

We have estimated the carbonate content to subtract it from the volumes of preserved sediments, in order to quantify the sediment supply derived from siliciclastic inputs. First, we have used the chronostratigraphic chart of Bueno et al. (2007) as well as the available wells to estimate the relative proportion of the dominant sediment types: sand, silt, clay and carbonate mud (Table 4). The volumes of each sediment type were corrected from remaining porosity using the method of Poag \& Sevon (1989) on the available wells (Table 4). We have estimated that the carbonate mud content ranges between $5 \%$ and $35 \%$ for the Paleocene $(\mathrm{I})$ and the Plio-Quaternary $(\mathrm{X})$ respectively (Table 4). The associated variance for the sediment supply ranges from $0.3 \%$ to $0.5 \%$ (Fig. 10c).

We have also investigated the influence of the dataset extraction from the chronostratigraphic chart of Bueno et al. (2007) and the available wells to define a scenario for the maximum possible estimation of siliciclastic versus carbonate content (mud), and one for the minimum. The associated variance for the sediment supply ranges from $4.4 \%$ to $14.3 \%$ (Fig. 10c).

The influence of post-depositional redistribution of sediments by erosion (i.e., erosion, bottom currents) or deformation is a major theme on itself and was out of the objective of the current research. A very detailed geological model, including a restoration of the bottom currents for each time interval, should be necessary to accomplish this assessment. Therefore, the preserved volumes presented and discussed hereafter could be considered as a milestone to quantify re-sedimentation processes for the Pelotas basin in the future.

\section{DISCUSSION}

Validation of the method: comparison with previous results

Only a few S2S studies address the evolution of this segment of the South American margin in comparison to those on its African conjugate (e.g. Rust \& Summerfield, 1990; Rouby et al., 2009; Guillocheau et al., 
2012), and none of them covered the entire basin. Contreras et al. (2010) performed a sediment flux quantification ( $\mathrm{m}^{2} / \mathrm{Myr}$ ) along a 2D profile near the Rio Grande cone, corresponding to our section 3 (Fig. 5). They identified low 2D sediment flux values during the early Paleogene, and a progressive increase until the pulse at the Late Eocene-Early Oligocene (ca. 34Ma). Late Oligocene to Early Miocene was characterized by a moderate sediment flux evolving towards a final pulse during the Plio-Quaternary, that is their maximum for the Cenozoic. These overall trends, identifiable on large-scale depositional units and in 2D, are consistent with our 3D quantification (Fig. 8).

In the Rio de la Plata area, sediment supply has been considered to range between 57 and $130 \times 10^{6} \mathrm{t} / \mathrm{yr}$ (ca. $35,000-80,000 \mathrm{~km}^{3} /$ Myr assuming a dry sand density of $1631 \mathrm{~kg} / \mathrm{m}^{3}$ ) primarily based on quaternary to present-day deposits studies (Depetris \& Griffin, 1968, Depetris et al., 1996, Giberto et al., 2004). Numerous databases have also published the current sediment flux at the mouth of the major Paraná river (ca. 62,200 km³/Myr; Hovius, 1998). Our mean value estimated for the Cenozoic of ca. 50,000 $\mathrm{km}^{3} / \mathrm{Myr}$ lies in the same order of magnitude of these previous studies, as well as the range of the first two sediment supply pulses $\left(5,000-150,000 \mathrm{~km}^{3} / \mathrm{Myr}\right)$.

However, the magnitude of the pulses exceeding 4, 5 or even 10 times the average value for the Cenozoic are more challenging to interpret. The time periods considered for pulses 5, 9 and 10 are short ( $<0.5 \mathrm{Myr})$ which may explain part of these high values (Sadler effect), however even if they lasted twice longer, they would still be anomalously high values. There is either additional flux from another source, or a change in the erosion dynamics in the catchments, discharging larger amounts of material during brief periods. The coastal plain and continental shelf of the Pelotas basin were deeply dissected during the Late Pleistocene lowstands by fluvial channels (Weschenfelder et al., 2014). The resulting paleodrainage networks directly linked the coastal catchments to the slope of the Pelotas basin. This configuration may have played an important role in maximizing the sediment supply during short periods, such as for pulses 9 and 10 .

Several cycles characterized by large pulses with growth phases (lasting $1 \mathrm{Myr}$ ), constant phases (1-2 Myr), and exponential decreasing phases (2-5 Myr) were identified in the sedimentary fill of the Pelotas basin. These pulses alternate with phases where the sediment supply was very low for intervals of around 1-5 Myr. Such shapes are already known mainly from experimental approaches (Schumm \& Rea, 1995; Bonnet \& Crave, 2003; Rohais et al., 2012). Only the pioneer work of Schumm \& Rea (1995) identified major pulses resembling closely to ours, in terms of shape and duration, based on normalized average sediment flux from the Himalayas to the northern Indian Ocean. We thus agree with their conclusions 
regarding the application of sediment supply curve inversion as an independent tool to be used in the prediction and interpretation of both short- and long-term geologic phenomena.

\section{Controlling factors on the siliciclastic budget of the Pelotas margins}

We propose a synthetic graph (Fig. 11) to illustrate and discuss the HR sediment supply dynamic recorded in the Pelotas basin (Fig. 11b) together with climate change and eustasy (Fig. 11c, d and e) and tectonic events and changes (Fig. 11e, f, g, h and g).

\section{Cenozoic climate change and eustasy}

Armijo et al. (2015) suggested that the Andean growth and global cooling may have operated under the same long-period forcing mechanism at plate-scale. They proposed that two climatic feedbacks causative of stepwise reductions of erosive power and precipitation over the Andean margin occurred during the Andean growth: one during the Mid-Eocene ( $42 \mathrm{Ma}$ ) climatic optimum, that lasted between 400 and 500 kyr (Bohaty et al., 2009; Westerhold \& Röhl, 2013); and a second erosive power reduction in the Late Miocene, a cooling period following the Mid-Miocene ( 17-15 Ma) climatic optimum. In the Pelotas basin fill, there is a lack of sedimentary pulse during, or just before, or even after the well-known climatic optima during the Cenozoic (Early Eocene, Mid-Eocene and Mid-Miocene, Fig. 11e). This suggests that major climatic changes could have been recorded in the foreland, but the resulting sediment supply pulse would have been buffered through the transfer area before arriving in the final sink (Pelotas sedimentary basin).

The high-value sediment supply pulses 8, 9 and 10 occurring during the Plio-Quaternary were recognized as short time duration cycles (ca. 0.3-0.5 Myr, Fig. 11b). This period is dominated by large variations in continental ice cover both near the poles and in the high mountains, known as the climatic Milankovitch cycles. Castelltort \& Van Den Driessche (2003) showed that Milankovitch-period variations in sediment supply from a high-elevation, fast-eroding landscape can be strongly buffered and are unlikely to be preserved in the depositional record. In a different way, Braun et al. (2015) showed, using numerical solutions, that rainfall variability at Milankovitch periods should affect the erosional response of fast uplifting mountain belts, with 1 to 10 kyr offsets between forcing and response. We do not have the time resolution to correlate the identified sedimentary pulses recorded in the Pelotas basin with Milankovitch cycles. However, we can speculate that major erosion changes induced by Milankovitch cycles were recorded by Qs cyclicity in the final sink. We propose that the high frequency and repetitive character of 
the Milankovitch cycles and resulting base level changes sufficiently affect the erosion dynamics all along the source-to-sink system to be recorded in the final sink.

Two small sediment supply pulses also occurred during major oceanic circulation changes: Pulses 2 and 3 , at 34 and $30 \mathrm{Ma}$ respectively (Fig. 11e). Pulse 2 is coeval with a Green-to-Icehouse transition, that also corresponds to the Tasmanian gateway opening influencing the deep-water circulation in the South Atlantic (Uenzelmann-Neben et al., 2017). Pulse 3 is coeval with the deep opening of the Drake Passage (Uenzelmann-Neben et al., 2017; Fig. 11). Even if it is impossible at this stage to decipher the relative contribution of tectonic versus oceanic circulation triggering mechanisms, their contemporaneity suggests a link between the Qs pulses 2 and 3 and oceanic circulation changes.

The interplay between eustatic change and sediment supply seems straightforward in this case study for Qs pulses 1,2, and 4. Pulses 1, 2 and 4 are the only ones to initiate abruptly after a major sequence boundary, Pr-1 (37.75 Ma), Ru-1 (33.89 Ma) and Aq-1 (23.03 Ma) respectively (Fig. 11c). These three surfaces occur at the end of greenhouse phases (Fig. 11e). It is also the period when sediment supply is relatively low and therefore small variations can be highlighted. The amplitude of the eustatic falls are accentuated during icehouse phases and it is possible that parts of the pulses 1, 2 and 4 record the propagation of the regressive erosion during sea level fall. The relocation of sediment from the inner shelf into deeper water can thus explain the shape of these three Qs pulses, suggesting that the real Qs entering the Pelotas basin was smoother than presently observed.

\section{Structural and tectonic forcing}

Considering the high amount of eroded material arriving in the Pelotas basin during the Cenozoic, the size of the catchments just upstream in Brazilian Rio Grande do Sul state (e.g. Lagoa dos Patos) and the Uruguayan coastal area do not seem large enough to provide that input. The Paraná river system (Río de la Plata) could have been a major player triggering the sediment supply to the Pelotas basin, with an extremely large drainage system initiating in the Andes (ca. $15-40^{\circ} \mathrm{S}$, Fig. 2). Consequently, one of the factors controlling the sediment supply dynamics of the Pelotas basin could be directly related to the tectonic history of the Andes.

The onset of Andean orogenesis and reversal in associated sedimentary polarity occurred at around 100 Ma for the southern Andes, and around 70-60 Ma for the rest of the orogen (Horton, 2018). Andean uplift starting during early Paleocene corresponds to the Laramide phase (ca. 60-58 Ma, Fig. 11e). It was followed by a long period of tectonic quiescence until the Incaic phase (ca. 42-38 Ma). This phase is coeval 
with a major westward propagation of the deformation front in the retroarc (Anderson et al., 2018). From Paleocene to Eocene, sediment supply to the Pelotas basin was very low (Fig. 11b), potentially because the sediment exported from the Andes was retained in the associated subsiding foreland basins. Moreover, during the Paleogene, most of the present-day Paraná catchment area was a low area dominated by lacustrine and restricted marine environments following the Late Cretaceous Atlantic ingression that flooded most of the continent (Marquillas \& Salfity, 1988, Gayet et al., 1993; Musacchio, 2000). This low land area could have acted as a large buffering area between the Andes and the Atlantic margin, limiting any sediment exports to the Pelotas basin.

The retroarc regions were dominated by tectonic quiescence following the late Eocene-early Miocene cessation of shortening in the frontal fold-thrust belt, with little to no accommodation being generated and highly condensed stratigraphic sections or unconformities developing in these areas (Horton, 2018). In the Pelotas basin, this time interval corresponds to the first well-recorded sedimentary pulses (Fig. 11b).

From ca. $26 \mathrm{Ma}$ to Present, the tectonic regime outside the sub-Andean retroarc foreland has been unstable, characterized by long periods of tectonic quiescence or constant rate of deformation separated by five short-lived generalized compressional events dated approximately at ca. 26, 17, 10, 7, and $2 \mathrm{Ma}$, respectively (e.g. Ellison et al., 1989; Sebrier \& Soler, 1991; Ramos \& Aleman, 2000; Jaillard et al., 2000; Ramos, 2010). These well-known phases are coeval with major changes in the rate of propagation of the deformation on the eastern side of the retroarc (Anderson et al., 2018; Horton, 2018, Fig. 11 e, f). In the Early-Middle Miocene, propagation of the inter-Andean Zone and Eastern Cordillera over the upper basement thrust sheet, induced eastward advance of flexural subsidence and influx of Andean sediments to fluvial systems in foredeep and wedge-top depozones (Calle et al., 2018). In the Pelotas basin, very low sediment supply is recorded (Fig. 11b). Surprisingly Fig. 11 shows that all the identified Qs pulses since the Late Paleogene occurred during tectonic quiescence or relatively stable phases, just after the end of main tectonic uplift phases. It is appealing to emphasize that the potential record of repetitive tectonic changes in the Andes in the Pelotas basin may account for the onset of transcontinental drainage, at least since the Oligocene.

The alternation of the main tectonic uplift phases with the sediment supply pulses also suggests a response time between the tectonic forcing occurring upstream in the river catchment (Source) and its final record in the sedimentary basin (Sink). A remarkable observation is that, despite different uplift phase durations, it is always at the end of the uplift phase marked by an abrupt change in the rate of 
propagation or the Andean deformation front (Fig. 11f) that the record in the sedimentary basin finally begins. This suggests that during the uplift phase changes, all the eroded material is stored upstream in the fluvial systems and at the foot of the reliefs, or eventually in intermediate storage as the Rio de la Plata estuary, and as soon as the uplift changes, all the material is exported to the continental margin with an almost instantaneous response time. For example, a large seaway associated with swamps and lakes developed at 8-10 Ma (just after pulses 5 and 6) in more than $50 \%$ of the Paraná catchment (Marshall et al., 1993), potentially acting as a buffering trap between the Andes (Source) and the Pelotas basin (Sink). Then Pulse 7 occurred rapidly after this period (Fig. 11b). We suggest that during tectonic uplift phase changes, the rejuvenation of the relief induced high sediment supply that was stored in the vicinity of the relief, and then during equilibrium-relief phase and relief lowering (i.e. tectonic quiescence), the previously stored sediment is dramatically exported towards the final sink, i.e. the continental margin sedimentary basin. This dynamic is in line with the two-phase model of foreland sedimentation proposed by Heller et al. (1988). Indeed, based on numerical flexural models, they proposed that during times of thrust-load emplacement and tectonic uplift, resulting sedimentation is immediately adjacent to the relief. During the post-orogenic phase of adjustment, a regional unconformity develops in the proximal part of the foreland basin, and previous proximal deposits are cannibalized and re-deposited in the distal foreland basin and beyond. Uplift onset of the southern portion Central Andean Plateau (hashed interval in Fig. 11f), where one of the tributaries of the Paraná river initiates, occurred at ca. $17 \mathrm{Ma}$ (Kar et al., 2016) and lasted until ca. $13 \mathrm{Ma}$ with very high surface uplift rate (Garzione et al., 2014; Anderson et al., 2018). The north-central segment of the Andean Plateau was rapidly uplifted since ca. $10 \mathrm{Ma}$ (Kar et al., 2016). The turnover between high uplift-rate to more moderate uplift-rate (ca. 13-12 Ma) is coeval with the main and maximal sediment supply pulse (Pulse 5) recorded in the Pelotas basin (Middle Miocene, VII, Fig. 11b). This period is also known as passive rejuvenation of the Eastern Cordillera and long-distance transport of coarse braided fluvial sediments (Calle et al., 2018).

For the Paraná river, a 2,000 km-long system, the response time is of around 392 to $784 \mathrm{Kyr}$ (Castelltort \& Van den Driessche , 2003). Repasch et al. (2020) recently quantified the time scales of sediment transport and storage in the Río Bermejo that is a $1300 \mathrm{~km}$-long affluent of the Parana river, using cosmogenic meteoric Beryllium-10. They estimate a transit time of around 8,500 years. This is consistent with our observations suggesting that during the post-orogenic phase of adjustment, the transfer of sediment rapidly initiated in the foreland basin to reach its final sink along the passive margin. In addition, the trends of the sedimentary pulse, marked by a rapid increase and followed by an exponential decrease,

This article is protected by copyright. All rights reserved 
suggest a relief which returns to its equilibrium state (Bonnet \& Crave, 2003; Lague et al. 2003; Rohais et al., 2012).

After minimum subsidence in the Late Cretaceous, the Paleocene to Eocene (65.5-33.9 Ma) are marked by a major increase in subsidence in the Pelotas basin (up to 55-80 m/Myr, Fig. 11i) contemporaneous with high Atlantic spreading rates, that has been interpreted as the result of a collapse of the continental margin during the early drift stage (Fontana, 1996; Contreras et al., 2010). This pattern correlates with a rise in the sediment supply and therefore is responsible for increasing flexural loading (Fig. 11). The Oligocene subsidence rates slightly decreased along the entire dip section, together with the Atlantic spreading rate (Fig. 11h, i). This pattern is interpreted as the result of crustal rebound, with a considerable lag time with respect to the strong Eocene subsidence trend, partially counterbalanced by sediment supply and flexural loading in the Oligocene (Contreras et al., 2010). During the Miocene, subsidence rates gently increased following a rapid increase of the Atlantic spreading rate (Fig. 11h).

It is worth noting that sediment delivery to the Pelotas Basin is influenced by both proximal, passive margin tectonic processes as well as distal tectonic processes in the Andes. It is consistent with the conclusions proposed by Rouby et al. (2013) based on numerical simulation. They effectively suggest that passive margins showing sediment supply pulses during their post-rift history have undergone other events than the simple thermal and flexural relaxation of the lithosphere stretching. This highlights the fact that the sedimentary basins located along mature passive margins have high potential to preserve climatic, tectonic and/or other processes controlling continental relief evolution at a geological time scale.

\section{Balancing the budget}

The Pelotas basin is not the only sink for the Paraná system, especially as the basin lies 200-km north of the outlet of this major river system. The Salado and Punta del Este basins located in front of the Río de la Plata estuary (Fig. 2) represent an additional area that is $50 \%$ as the size of the investigated area. In addition, our 3D quantification is restricted to the rectangle presented in Fig. 3. If we extended it to the mid-Atlantic ridge using the method presented by Guillocheau et al. (2012), we would further increase the estimated sediment accumulation values, suggesting that a complementary source responsible for adding sediments to the basin is necessary. These observations are consistent with evidence of a local additional sediment source coming from the Brazilian shield just up-dip from the Rio Grande Cone. There are also turbidites that apparently were fed from local sources in the northern part of the basin potentially coming

This article is protected by copyright. All rights reserved 
from the Santos basin shelf (Abreu, 1998). In situ production (organic matter, carbonate mud) could potentially explain these unbalanced results recorded by Qs pulses, especially as we do not have wells to control the lithology in the abyssal plain. Another input of sediment could be derived from distant sources, re-worked by oceanic circulation. Indeed, the well-developed bottom currents played a key role in shaping the margin (Hernández-Molina et al., 2016, Uenzelmann-Neben et al., 2017) and could explain such additional supplies.

\section{CONCLUSIONS}

We have developed and applied a workflow for HR sedimentary budget quantification in 3D and at regional basin scale. We applied this new workflow to the Pelotas Basin, where high-resolution seismic sequence stratigraphy was already well established. The volume of sediments was estimated for largescale depositional units. We have introduced the Representative Proportion Curve (RPC) on a 2D basinscale cross-section selected for higher resolution sequence stratigraphic assessment. The relative proportion of each interval was computed in $2 \mathrm{D}$ along the selected sections and then compared to the relative proportion of the interpreted 3D volumes for the entire basin to define a Correction Factor (CF). A Representative Proportion Curve was then computed at high-resolution (RPC-HR) along a regional, 2D dip section imaging a large part of this sedimentary basin. Then, we estimated the in-situ production and remaining porosity in order to correct the accumulated volumes considering only the terrigenous portion. High-resolution (time step ca. 1-2 Myr, for a basin fill of ca. $60 \mathrm{Myr}$ ) sediment supply quantification was finally carried out and discussed regarding the main uncertainties identified throughout the workflow and the main factors controlling the recorded response.

We determined the ranges of variance for the parameters used in this method: the uncertainties on seismic velocities for the time-to-depth conversion range between $5 \%$ and $22 \%$ of the volume of preserved sediments (nevertheless locally the variance could reach $60 \%$ ), on the absolute ages of stratigraphic markers (1-25\%), on the carbonate mud content (0.3-0.5\%), and on the method for lithological parameters quantification from dataset extraction and associated porosity correction (4.4-14.3 $\%)$. Our estimates of the sediment supply were validated by comparison with previous 2D estimates at a lower temporal resolution in the same area.

This method allows the identification of several cycles characterized by large pulses with growth phases lasting less than $1 \mathrm{Myr}$, constant phases lasting around 1-2 Myr, and exponential decreasing phases lasting 
2-5 Myr. These pulses alternate with phases where the sediment supply was very low for intervals of ca. 1-5 Myr.

It is also suggested that the sediment supply dynamics in the Pelotas basin record the known orogenic phases of the Andes (located more than 2,000 km upstream), a relationship which was not clear on largescale depositional units. The pulses recorded in the sedimentary basin (Sink) are out of phase with respect to the active tectonic phase changes of the Andes (Source). The complete S2S system seems to show an alternation between periods of sediment production and storage upstream during the active uplift phases (e.g. close to the source, foothills and fluvial systems in the foreland), then the export and final deposit in the ultimate sedimentary basin during the tectonic quiescence phase. These dynamics raise the question on system response time between the source, the transfer and the sink area, with potential intermediate response time to be defined.

By undertaking the total volumes of sediment, the Pelotas basin shows the particularity of containing more sediment than what the reliefs upstream could provide. This is particularly accentuated since the end of the Oligocene, when a transition from a Greenhouse period to an Icehouse period is recorded. This transition is also marked by the establishment of significant ocean circulation which could be the source of lateral and deep sediment supply into the basin, and thus explain the anomalies in the sedimentary mass balance. Additional possible local sediment sources from the north should also be investigated.

Finally, in order to understand the sediment budget, it is necessary to put the passive margin sedimentary basin on a plate tectonic framework, as well as on the scale of an ocean-continent couple. Therefore, it would also be necessary to present a detailed sedimentological and stratigraphic framework for a complete section from the Pelotas basin up to the Andes in order to establish the link with resedimentation events (i.e. bottom current, major unconformities), and to have better constrains on climatic models and changes in vegetation through time.

Ultimately, from a methodological perspective, we have illustrated that through a relatively simple workflow, it is possible to access trends and timing of sediment supply changes which can be quite relevant for all topics of interest in the S2S community. In a nutshell, in any sedimentary basin where the large-scale depositional units are already published, a HR seismic stratigraphy study on a dip section imaging a large portion of the basin would allow a quick establishment of sediment supply curves. When applied to sedimentary basins along mature passive margins, this methodology could bring major insights onto continental relief evolution at a geological time scale.

This article is protected by copyright. All rights reserved 


\section{Acknowledgements}

This research was funded by IFPEN. We thank the editor Peter Burgess and the reviewers, Tomas Capaldi, Cornel Olariu, Frank Pazzaglia, and two anonymous reviewers for their insightful reviews on a previous version of the manuscript.

The authors declared no conflict of interest.

\section{Data availability}

The data that support the findings of this study are available from the corresponding author upon request.

This article is protected by copyright. All rights reserved 
Fig. 1. Overview of the timescales of investigation, the periods and nature of some of the forcing mechanisms on depositional systems and associated sediment supply (blue for climate-driven, and orange for tectonically-driven), and the chronometric tools and methods (black for absolute dating, and green for relative) commonly used in sedimentary basin analysis (modified from Romans et al., 2016 and references therein).

Fig. 2. Location of the study area (white rectangle) in the Pelotas basin. The present-day hydrographic basin of the Paraná river is indicated upstream of the Río de la Plata $\left(2,600,000 \mathrm{~km}^{2}\right)$. The present-day bottom currents are also illustrated (modified from Hernández -Molina et al., 2009; 2016; Razik et al., 2015). RdIP= Rio de la Plata, Sal.= Salado basin, PdE= Punta del Este basin, RGC= Rio Grande Cone, San.=Santos basin. DEM in meters from the ETOPO1 Global Relief Model (https://www.ngdc.noaa.gov/mgg/global/). Bathymetry in meters from the GEBCO Grid (https://www.gebco.net/data_and_products/gridded_bathymetry_data/). See text for further explanations.

Fig. 3. Dataset used in this study to constrain the geometry of the sedimentary basin fill. A. Location map: Argentina (Arg), Uruguay (U), Brazil (Br), Paraguay (P), Bolivia (Bo). B. Pelotas basin Dataset map. The main depocenter of the Pelotas basin corresponds to the Rio Grande Cone (RGC). The main present-day drift systems are illustrated: Chui, Rio Grande, Pelotas and Santa Catarina Drifts (Jeck et al., 2019). Tectonic arches from Justus et al. (1986), Soto et al. (2011) and references therein. Martin García Arch (MG), Polonio Arch (P), Rio Grande Arch (RG), Torres Arch (T), Florianopolis High (F). PdE= Punta del Este basin, Santos= Santos basin. Bathymetry from the GEBCO Grid (https://www.gebco.net/data_and_products/gridded_bathymetry_data/). The black rectangle illustrates the area of interest for 3D sedimentary budget quantification. See details for seismic and well data in Table 1. The four highlighted seismic lines (1-4) correspond to the interpreted sections presented in Figure 5. Projection UTM84 (20S)

Fig. 4. Methodology chart presenting the workflow for HR sedimentary budget quantification. Five main stages are illustrated, including sub-stages. See text for further explanations.

This article is protected by copyright. All rights reserved 
Fig. 5. Four main dip cross-sections (in TWT) illustrating the eleven large-scale depositional units of the sedimentary basin fill in the Pelotas basin (see Fig. 3 for location). (1) Composite interpreted section of seismic profiles 0228-0327 and LEPLAC-IV 048 including the work of Barbosa et al. (2008), Abreu (1998), Abreu et al. (2010), Fontana (1996) and Bassetto et al. (2000). (2) Interpreted section of seismic profiles 0228-0317 including the work of Fontana (1996) and Abreu (1998). (3) Interpreted section of seismic profile 0239-0370 including the work of Fontana (1996) and Contreras et al. (2010). (4) Interpreted section of seismic profiles presented in figure 38 of Conti et al. (2017). Keys: X. Plio-Quaternary, IX. Uppermost Miocene, VIII. Upper Miocene, VII. Middle Miocene, VI. Lower Miocene, V. Upper Oligocene, IV. Lower Oligocene, III. Mid- Upper Eocene, II. Lower Eocene, I. Paleocene. and Cretaceous undifferentiated.

Fig. 6. Thickness maps for the Cenozoic units (I-X) and Cretaceous (undifferentiated) in the Pelotas basin. Contour lines every 500m, with same color scale for all the maps. Polonio Arch (PA), Torres Arch (TA), and Florianopolis High (FH) are highlighted using the same legend as in Fig. 3. The white dashed line corresponds to the present-day coastline. Keys: X. Plio-Quaternary, IX. Uppermost Miocene, VIII. Upper Miocene, VII. Middle Miocene, VI. Lower Miocene, V. Upper Oligocene, IV. Lower Oligocene, III. MidUpper Eocene, II. Lower Eocene, I. Paleocene. and Cretaceous undifferentiated.

Fig. 7. Dip cross-sections (in TWT) illustrating the raw section profile 0228-0327 ( 1 in Fig. 3 and 5). The eleven large-scale depositional units of the sedimentary basin fill in the Pelotas basin are indicated in (b), while the $41 \mathrm{HR}$ stratigraphic intervals used in this study are shown in (c). The composite section is based on the interpretation of seismic profiles 0228-0327 and LEPLAC-IV 048 including, from left to right the work of Barbosa et al. (2008), Abreu (1998), Abreu et al. (2010), Fontana (1996) and Bassetto et al. (2000), respectively.

Fig. 8. Graphs showing the establishment of the corrected RPC-HR 2D (D.) for the dip composite-section 1 presented in Fig. 7 (0228-0327 and LEPLAC-IV 048). The RPC-HR 2D is based on a comparison between the RPC 3D using the large-scale depositional units of the entire basin fill (A.) and the RPC 2D using the large-

This article is protected by copyright. All rights reserved 
scale depositional units on composite-section 1 (B.) to define the Corrective Factor (CF), and the computation of the RPC-HR 2D on the same composite section (C.). Keys: X. Plio-Quaternary, IX. Uppermost Miocene, VIII. Upper Miocene, VII. Middle Miocene, VI. Lower Miocene, V. Upper Oligocene, IV. Lower Oligocene, III. Mid- Upper Eocene, II. Lower Eocene, I. Paleocene. See text for further explanations.

Fig. 9. Graphs showing the lithology and porosity correction for the HR sediment supply quantification. The sediment supply defined at low resolution using the large-scale depositional units is combined first with the RPC-HR defined in 2D, and then corrected from the relative proportion of sand, silt, clay and carbonate mud to adjust from the in-situ production (carbonate) and their associated remaining porosity. Circled numbers 1-10 corresponds to the pulses discussed in the text. Keys: X. Plio-Quaternary, IX. Uppermost Miocene, VIII. Upper Miocene, VII. Middle Miocene, VI. Lower Miocene, V. Upper Oligocene, IV. Lower Oligocene, III. Mid- Upper Eocene, II. Lower Eocene, I. Paleocene. See text for further explanations.

Fig. 10. Sensitivity analysis of the main parameters used during the computation of the HR sediment supply. Influence of time-to-depth conversion (A), age model (B) and lithology/porosity correction (C) on sediment supply quantification. The preferred reference model is highlighted in black. Keys: X. PlioQuaternary, IX. Uppermost Miocene, VIII. Upper Miocene, VII. Middle Miocene, VI. Lower Miocene, V. Upper Oligocene, IV. Lower Oligocene, III. Mid- Upper Eocene, II. Lower Eocene, I. Paleocene. See text for further explanations.

Fig. 11. Synthetic chart illustrating the high-resolution sediment supply dynamics in the Pelotas basin (a, b) and some potential forcing mechanisms such as eustasy (c, d), main climatic and oceanic circulation (e), and tectonic events and deformation proxies ( $f, g, h, i)$. The rate of propagation of the Andean deformation front is from Anderson et al. (2018). Green lines underline the mean value, and the boxes the associated errors. The Central Andean Plateau elevation (g) is from Kar et al. (2016). Atlantic spreading rate is from Brozena (1986). Subsidence rate in the Pelotas basin is from Contreras et al. (2010), and the main climatic, oceanic circulation and tectonic events from Sébrier \& Soler (1991), Hernández-Molina et al. (2016) and Uenzelmann-Neben et al. (2017) and references therein. Keys: X. Plio-Quaternary, IX. 
Uppermost Miocene, VIII. Upper Miocene, VII. Middle Miocene, VI. Lower Miocene, V. Upper Oligocene, IV. Lower Oligocene, III. Mid- Upper Eocene, II. Lower Eocene, I. Paleocene. Numbers in circle (1-10) indicate the major sedimentary pulses. See text for further explanations.

This article is protected by copyright. All rights reserved 
Table 1. List of data. Wells are informed in lithology, biostratigraphy, geochronology and are tied to seismic from the cited authors.

Table 2. Surface, age models, marker and time-to-depth conversion (well P4, 1-SCS-0002-SC, seismic profile 0223-0327). The initial age model of Abreu (1998) has been updated to match the ICS stratigraphic chart based on the synthesis by Gradstein et al. (2012).

Table 3. Relative proportions computed for the large-scale seismic units along the four dip-sections presented in Fig. 5, and comparison with the relative proportion of the large-scale seismic units computed in $3 D$ at basin scale to define the Correction Factor (CF). See text for further explanations.

Table 4. Dataset used to compute the HR sediment supply in the Pelotas basin and assess the sensitivity analysis to time-to-depth conversion, lithology and associated porosity uncertainties. The preferred model is presented, as well as the minimum and maximum of the tested values (in brackets).

This article is protected by copyright. All rights reserved 


\section{REFERENCES}

Abreu, V.S. (1998). Geologic evolution of conjugate volcanic passive margins: Pelotas Basin (Brazil) \& offshore Namibia (Africa). Implication for global sea-level changes. PhD Thesis, Rice University, Houston, Texas, $354 \mathrm{p}$.

Abreu, V.S., \& Neal J.E., Vail P.R. (2010). Integration of Sequence Stratigraphy concepts. In: Abreu V.S., Neal J.E., Bohacs K.M., Kalbas J.L. (eds.). Sequence Stratigraphy of siliciclastic systems - The ExxonMobil Methodology: atlas of exercises, SEPM Concepts in Sedimentology \& Paleontology, 9:209-224.

Allen, P. (2008). From landscapes into geological history. Nature 451 (7176), 274-276.

http://dx.doi.org/10.1038/nature06586.

Anderson, RB., Long, SP., Horton, BK., Thomson, SN., Calle, AZ., Stockli, DF. (2018) Orogenic Wedge Evolution of the Central Andes, Bolivia ( $\left.21^{\circ} \mathrm{S}\right)$ : Implications for Cordilleran Cyclicity: Tectonics, v. 37, p. 3577-3609, doi:10.1029/2018TC005132.

Armijo, R., Lacassin, R., Coudurier-Curveur, A., Carrizo, D. (2015) Coupled tectonic evolution of Andean orogeny and global climate. Earth-Science Reviews 143 (2015) 1-35 http://dx.doi.org/10.1016/j.earscirev.2015.01.005

Armitage, JJ., Dunkley Jones, T., Duller, RA., Whittaker, AC., Allen, PA. (2013) Temporal buffering of climate-driven sediment flux cycles by transient catchment response. Earth Planet. Sci. Lett. 369, 200210.

Barboza, E. G., Rosa, M. L. C. C., Ayup-Zouain, R. N. (2008). Cronoestratigrafia da Bacia de Pelotas: uma revisão das seqüências deposicionais. Gravel (Porto Alegre), v. 6, p. 125-138.

Bassetto, M., Alkmim, F., Szatmari, P., Mohriak, W.U. (2000). The oceanic segment of the southern Brazilian margin: morpho-structural domains and their tectonic significance. In: Mohriak, W.U., Talwani, M. (Eds.), Atlantic Rifts and Continental Margins. American Geophysical Union, Monograph, vol. 115, pp. 235-259.

Berggren, W.A., Kent, D.V., Swisher, C.C., Aubry, M.-P. (1995) A revised Cenozoic geochronology and chronostratigraphy. Geochronology Time Scales and Global Stratigraphic Correlation, SEPM Special Publication 54, 129-212.

This article is protected by copyright. All rights reserved 
Bhattacharya, J.P., Copeland, P., Lawton, T.F., Holbrook, J. (2016). Estimation of source area, river paleodischarge, paleoslope, and sediment budgets of linked deep-time depositional systems and implications for hydrocarbon potential. Earth Sci. Rev. 153, 77-110.

Blaich, O.A., Faleide, J.I., Tsikalas, F., Franke, D., León, E. (2009). Crustal-scale architecture and segmentation of the Argentine margin and its conjugate off South Africa. Geophysical Journal International, 1-21.

Bohaty, S. M., J. C. Zachos, F. Florindo, M. L. Delaney (2009). Coupled greenhouse warming and deep-sea acidification in the Middle Eocene, Paleoceanography, 24, PA2207, doi:10.1029/2008PA001676.

Bonnet, S., \& Crave, A. (2003). Landscape response to climate change: insights from experimental modeling and implications for tectonic versus climatic uplift of topography. Geology 31, 123-126.

Braun, J., Voisin, C., Gourlan, AT., Chauvel C. (2015) Erosional response of an actively uplifting mountain belt to cyclic rainfall variations. Earth Surf. Dynam., 3, 1-14, 2015 www.earth-surf-dynam.net/3/1/2015/. doi:10.5194/esurf-3-1-2015

Brozena, J. M., (1986). Temporal and Spatial Variability of Seafloor Spreading Processes in the Northern South Atlantic,J. Geophys. Res. 91, 497-510.

Bueno, G.V., Zacharias, A.A., Oreiro, S.G., Cupertino, J.A., Falkenhein, F.U.H., Martins, M.A. (2007). Bacia de Pelotas. Boletim de Geociências da Petrobras, Rio de Janeiro 15 (2), 551-559.

Calle, AZ., Horton, BK., Limachi, R., Stockli, DF., Uzeda-Orellana, GV., Anderson, RB., Long, SP. (2018) Cenozoic provenance and depositional record of the Subandean foreland basin during growth and advance of the central Andean fold-thrust belt, southern Bolivia.: Petroleum basins and hydrocarbon potential of the Andes of Peru and Bolivia, p. 459-506, doi:10.1306/13622132M1173777.

Calvès, G., Toucanne, S., Jouet, G., Charrier, S., Thereau, E., Etoubleau, J., Marsset, T., Droz, L., Bez, M., Abreu, V. (2012). Inferring denudation variations from the sediment record; an example of the last glacial cycle record of the Golo Basin and watershed, East Corsica, western Mediterranean sea. Basin Res. 2013, 25, 197-218.

Cardozo, T. (2011). Caracterização do arcabouco estrutural da bacia de Pelotas e da área emersa adjacente. Universidade Estadual Paulista, Rio Claro, Sao Paul, PhD.

This article is protected by copyright. All rights reserved 
Castelltort, S., \& Van den Driessche, J. (2003). How plausible are high-frequency sediment supply-driven cycles in the stratigraphic record? Sediment. Geol. 157, 3-13.

Castillo, L., \& Chemale, F.J. (2014). Seismostratigraphy and Geomorpholgy of the Rio Grande Cone, Pelotas basin (Brazilian Offshore). Geología Colombiana, v. 39, p. 55-71.

Chen, S., Steel, R., Olariu, C. Li, S. (2017) Growth of the paleo-Orinoco shelf-margin prism: Process regimes, delta evolution, and sediment budget beyond the shelf edge. GSA Bulletin ; 130 (1-2): 35-63. doi: https://doi.org/10.1130/B31553.1

Cobbold, P.R., Rosello, E.A., Roprech, P., Arriagada, C., Gómez, L.A., Cláudio, L. (2007). Distribution, timing, and causes of Andean deformation across South America. In: Ries, A.C., Butler, R.W.H., Graham, R.H. (Eds.), Deformation of the Continental Crust: The Legacy of Mike Coward. Geological Society of London, Special Publications, vol. 272, pp. 321-343.

Conti, B., Perinotto, J.A., Veroslavsky, G., Castillo, M.G., de Santa Ana, H., Soto, M., Morales, E. (2017). Speculative petroleum systems of the southern Pelotas Basin, offshore Uruguay. Mar. Pet. Geol. 83, 1-25.

Contreras, J., Zühlke, R., Bowmanb, S., Bechstädt, T. (2010). Seismic stratigraphy and subsidence analysis of the southern Brazilian margin (Campos, Santos and Pelotas basins). Mar. Pet. Geol. 27, 1962-1980.

Coimbra, J.C., Carreño, A.L., Anjos, G.S. (2009). Biostratigraphy and paleoceanographical significance of the Neogene planktonik foraminifera from the Pelotas Basin, southernmost Brazil. Revue de Micropaléontologie 52, 1-14.

Corrêa, T.B.S. (2004). Evolução Espaço-Temporal dos Principais Depocentros da Sequência Sedimentar Marinha da Bacia de Pelotas. Bcs Rio de Janeiro, RJ - Universidade do Estado do Rio de Janeiro - UERJ, Instituto de Geociências, Departamento de Oceanografia.

Creaser, A., Hernández-Molina, F.J., Badalini, G., Thompson, P., Walker, R., Soto, M., Conti, B. (2017). A Late Cretaceous mixed (turbidite-contourite) system along the Uruguayan Margin: sedimentary and palaeoceanographic implications. Mar. Geol. 390, 234-253.

Cruz, L.V. (2011). Interpretação sismostratigrafica do norte de bacia de Pelotas. Universidade Federal da Bahia, Salvador, PhD.

Depetris, P. J., \& Griffin, J. J. (1968). Suspended load in the Río de la Plata drainage basin. Sedimentology, 11(1-2), 53-60.

This article is protected by copyright. All rights reserved 
Depetris, P.J., Kempe, S., Latif, M., Mook, W.G. (1996). ENSO-controlled flooding in the Paraná River (1904-1991).Naturwissenschaften83,127-129.

Dias, J.L., Sad, A.R.E., Fontana, R.L., Feijo, F.J. (1994). Rio de Janeiro. Bacia de Pelotas. Boletim de Geociencias da Petrobras, vol. 8, pp. 235e245.

Ellison, R.A., Klinck, B.A., Hawkins, M.P. (1989). Deformation events in the Andean orogenic cycle in the Altiplano and Western Cordillera, southern Peru. Journal of South American Earth Sciences. Volume 2, Issue 3, 1989, Pages 263-276. https://doi.org/10.1016/0895-9811(89)90033-3

Fontana, R.L. (1987). Desenvolvimento termomecanico da Bacia de Pelotas e parte sul da Plataforma de Florianopolis. Dissertaçao de Mestrado, Universidade Federal de Ouro Preto, Minas Gerais.

Fontana, R.L. (1989). Evidências Geofísicas da presença de Hidratos de Gás na Bacia de Pelotas - Brasil. 10 Cong. Soc. Bras. Geofísica, vol.7(1), p. 93.

Fontana, R.L. (1996). Geotectonica e sismoestratigrafia da Bacia de Pelotas e Plataforma de Florianopolis. Tese de doutorado em Geociencias. Universidade Federal do Rio Grande do Sul, Porto Alegre.

Franke, D., Neben, S., Ladage, S., Schreckenberger, B., Hinz, K. (2007). Margin segmentation and volcanotectonic architecture along the volcanic margin off Argentina/ Uruguay, South Atlantic. Mar. Geol. 244, 46-67.

Franke, D., Ladage, S., Schnabel, M., Schreckenberger, B., Reichert, C., Hinz, K. (2010). Birth of a volcanic margin off Argentina, South Atlantic. Geochemistry Geophysics Geosystems, 11(2), 1-20.

Gallagher, K., Brown, R.W. and Johnson, C. J. (1998). Geological Applications of Fission Track Analysis, Annual Reviews of Earth and Planetary Sciences, 26, 519- 572.

Galloway, WE. (1975). Process framework for describing the morphologic and stratigraphic evolution of deltaic depositional systems. In: Broussard, M.L. (ed.), Deltas: Houston Geol. Soc., pp.87-98.

Galloway, WE. (2001) Cenozoic evolution of sediment accumulation in deltaic and shore-zone depositional systems, Northern Gulf of Mexico basin. Marine and Petroleum Geology, v. 18, pp. 1031-1040.

Galloway, WE., Whiteaker, TL., Ganey-Curry, P. (2011) History of Cenozoic North American drainage basin evolution, sediment yield, and accumulation in the Gulf of Mexico basin: Geosphere, v. 7, p. 938-973, doi:10.1130/ges00647.1.

This article is protected by copyright. All rights reserved 
Garcia, W.O. (2012). Estudo da influência do lineamento Tibagi e sinclinal de Torres na estruturação da porção norte da bacia de Pelotas. MSc, UNESP - Universidade Estadual Paulista, Campus de Rio Claro (SP). $71 \mathrm{p}$.

Gayet, M., Sempere, T., Cappetta ,H., Jaillard, E., Lévy, A. (1993). La présence de fossiles marins dans le Crétacé terminal des Andes centrales et ses conséquences paléogéographiques. Palaeo Palaeoc Palaeoe 102:283-319

Giberto, D. A., Bremec, C. S., Acha, E. M., Mianzan, H. W. (2004). Large-scale spatial patterns of benthic assemblages in the SW Atlantic: the Río de la Plata estuary and adjacent shelf waters. Estuar. Coast. Shelf Sci. 61:1-13.

Godard, V., Tucker, GE., Burch Fisher, G., Burbank, DW., Bookhagen, B. (2013) Frequency-dependent landscape response to climatic forcing. Geophys. Res. Lett. 40 (5), 859-863.

González-Bergonzon,. I., Marcelo Loureiro, M., Oviedo, S. (2009). A new species of Gymnogeophagus from the río Negro and río Tacuarí basins, Uruguay (Teleostei: Perciformes). Sociedade Brasileira de Ictiologia. Neotropical Ichthyology, 7(1):19-24

Gradstein, F.M., Ogg, J.G., Schmitz, M.D., Ogg, G.M. (2012). The Geologic Time Scale. Elsevier doi:10.1016/B978-0-444-59425-9.10003-4

Grassmann, S., Franke, D., Neben, S., Schnabel, M., Damm, V. (2011). Maturity modelling of the deepwater continental margin, offshore Argentina. Z. Dtsch. Ges. Geowiss. 162/1, 79-89.

Guillocheau, F., Rouby, D., Robin, C., Helm, C., Rolland, N., Le Carlier de Veslud, C., Braun, J. (2012). Quantification and causes of the terrigeneous sediment budget at the scale of a continental margin: a new method applied to the Namibia-South Africa margin. Basin Research, 24: 3-30. doi:10.1111/j.13652117.2011.00511.x

Haq, B.U., Hardenbol J., Vail. P. (1987). Chronology of fluctuating sea levels since the Triassic. Science, v. 235, p. 1156-1167.

Heller, PL., Angevine, CL., Winslow, NS., Paola, C. (1988) Two-phase stratigraphic model of foreland: Geology, v.16, p. 501-504, doi:10.1130/0091- 7613(1988)016<0501. 
Henry, F., Probst, J. L., Thouron, D., Depetris, P. J., Garçon, V. (1996). Nd-Sr isotopic compositions of dissolved and particulate material transported by the Paraná and Uruguay rivers during high (december 1993) and low (september 1994) water periods. Sciences Géologiques, Bulletin, 49(1-4), 89-100.

Hernández-Molina, F.J., Paterlini, M., Violante, R., Marshall, P., de Isasi, M., Somoza, L., Rebesco, M. (2009). Contourite depositional system on the Argentine Slope: an exceptional record of the influence of Antarctic water masses. Geology 37:507-510

Hernández-Molina, F.J., Paterlini, M., Somoza, L., Violante, R., Arecco, M.A., de Isasi, M., Rebesco, M., Uenzelmann-Neben, G., Neben, S., Marshall, P. (2010). Giant mounded drifts in the Argentine continental margin: origins, and global implications for the history of the thermohaline circulation. Marine and Petroleum Geology 27, 1508-1530.

Hernández-Molina, F.J., Soto, M., Piola, A., Tomasini, J., Preu, B. (2016). A contourite depositional system along the Uruguayan continental margin: Sedimentary, oceanographic and paleoceanographic implications. Marine Geology 378 (2016) 333-349.

Horn, B. (2015). Access and exploration opportunities - A view of the potential in frontier and mature basins. First break volume 33.

Horton, B.K. (2018). Sedimentary record of Andean mountain building. Earth-Science Reviews, Volume 178, March 2018, Pages 279-309. https://doi.org/10.1016/j.earscirev.2017.11.025

Hovius, N. (1998). Controls on sediment supply by large rivers. In: Shanley, K.W., McCabe, P.J. (Eds.), Relative Role of Eustasy, Climate and Tectonism in Continental Rocks. Soc. Econ. Paleontol. Mineral. Spec. Publ., vol. 59, pp. $3-16$. Tulsa.

Jackson, M.P.A., Cramez, C., Fonck, J.M. (2000). Role of subaerial volcanic rocks and mantle plumes in creation of South Atlantic volcanic margins: implications for salt tectonics and source rocks. Marine and Petroleum Geology 17, 477e498.

Jeck, I.K., Alberoni, A.A.L., Torres, L.C. et al. (2019). The Santa Catarina Plateau and the nature of its basement. Geo-Mar Lett. https://doi.org/10.1007/s00367-019-00585-z

Jones, S.M., White, N.J., Clarke, B.J., Rowley, E., Gallagher, K. (2002). Present and past influence of the Iceland Plume on sedimentation. In: Dore, A.G., Cartwright, J.A., Stocker, M.S., Turner, J.P., White, N.J.

This article is protected by copyright. All rights reserved 
(Eds.), Exhumation of the North Atlantic Margin. Geological Society, Special Publications, London, pp. 1325.

Justus, J.O., Machado, M.L.A., Franco, M.S.M. (1986). Geomorfologia. In: Levantamento de Recursos Naturais 33. Rio de Janeiro, Instituto Brasileiro de Geografia e Estatística. p. 313-404

Kar N., Garzione, C.N., Jaramillo, C., Shanahan, T., Carlotto, V., Pullen, A., Moreno, F., Anderson, V., Moreno, E., Eiler, J. (2016). Rapid regional surface uplift of the northern Altiplano plateau revealed by multiproxy paleoclimate reconstruction. Earth Planet. Sci. Lett., 447 (2016), pp. 33-47

Kowsmann, R. O., Costa M.P., Boa Hora M.P., Almeida H.P., Guimaraes P.P. (1982). Geologia estrutural do Plato de Sao Paulo. In: Anais do XXXII Congresso Brasileiro de Geologia, Salvador, Brazil, SBG, v.4: pp. 1558-1569.

Krastel, S., Wefer, G., Hanebuth, T.J.J., Antobreh A.A., Freudenthal T., Preu B., Schwenk T., Strasser M., Violante R., Winkelmann D. (2011). Sediment dynamics and geohazards off Uruguay and the de la Plata River region (northern Argentina and Uruguay). Geo-Mar Lett 31, 271-283 (2011).

https://doi.org/10.1007/s00367-011-0232-4

Lague, D., Crave, A., Davy, P. (2003). Laboratory experiments simulating the geomorphic response to tectonic uplift. J. Geophys. Res. 108

Lopes da Silva, M. (2013). Definição do comportamento morfoestrutural da zona de fratura de porto alegre. BcS, Universidade Federal Fluminense, 62p.

Lovecchio, J.P., Rohais, S., Joseph, P., Bolatti, N., Kress, P.R., Gerster, R., Ramos, V.A. (2018). Multi-stage rifting evolution of the Colorado basin (offshore Argentina): Evidence for extensional settings prior to the South Atlantic opening. Terra Nova. https://doi.org/10.1111/ter.12351

Lovecchio, J.P., Rohais, S., Joseph, P., Bolatti, N., Ramos, V.A. (2020). Mesozoic rifting evolution of SW Gondwana: A poly-phased, subduction-related, extensional history responsible for basin formation along the Argentinean Atlantic margin, Earth-Science Reviews, https://doi.org/10.1016/j.earscirev.2020.103138

Machado, L.G. (2010). Evolução morfo-tectônica do Alto de Florianópolis que segmenta as bacias de Santos e Pelotas, margem sudeste da costa brasileira. McS, Universidade Federal Fluminense, 125p.

This article is protected by copyright. All rights reserved 
Marquillas, R.A., Salfity, J.A. (1988). Tectonic framework and correlations of the Cretaceous-Eocene Salta Group, Argentine. In: Bahlburg H, Breitkreuz Ch, Giese P (eds) The Southern Central Andes. Springer, Berlin Heidelberg New York. Lect Notes Earth Sci 17:119-136

Marshall, L.G., Sempere, T., Gayer, M. (1993). The Pecta (Late Oligiocene-Miocene) and Yecua (Late Miocene) Formations of the Sub Andean-Chaco Basin, Bolivia and their tectonic significance. Document Laboratoire Géologie Université Lyon, France, 125. 291-301.

Martins, L.R., Urien C.M., Martins, I.R. (2005). Gênese dos Sedimentos da Plataforma Continental Altantica entre o Rio Grande do Sul (Brasil) e Terra del Fuego (Argentina): Gravel Geológica, v. 3, p. 85-102.

Métivier, F., Gaudemer, Y., Tapponnier, P., Klein, M. (1999) Mass accumulation rates in Asia during the Cenozoic. Geophysical Journal International, 137 (2), pp.280-318.

Milliman, J. D., \& Meade, R. H. (1983). World-wide delivery of river sediment to the oceans. The Journal of Geology, 91(1), 1-21.

Milliman JD, \& Syvitski JPM, 1992. Geomorphic/tectonic control of sediment discharge to the ocean: The importance of small mountainous rivers. J. Geol. 100: 525-544

Morales, E. (2013). Evolução tectonica e estratigrafica das bacias da margem continental do Uruguai. Universidade Estadual Paulista, Rio Claro, Sao Paulo. PhD.

Morales, E., Chang, H.K., Soto, M., Santos Corrêa, F., Veroslavsky, G., de Santa Ana, H., Conti, B., Daners, G. (2017). Tectonic and stratigraphic evolution of the Punta del Este and Pelotas Basins (offshore Uruguay). Pet. Geosci. 23, 415-426.

Morales, E., Conti B., Soto M., Viera-Honegger B. (2020). Risks inherent in the Cenozoic stratigraphic plays in basins of the Uruguayan continental margin. Marine and Petroleum Geology 112 (2020) 104072. https://doi.org/10.1016/j.marpetgeo.2019.104072

Mohriak, W.U., Rosendahl, B.R., Turner, J.P., Valente, S.C. (2002). Crustal architecture of South Atlantic volcanic margins. In: Menzies, M.A., Klemperer, S.L., Ebinger, C.J., Baker, J. (Eds.), Volcanic Rifted Margins. Special Paper Geological Society of America vol. 362, 159e202.

Musacchio, E.A. (2000). Biostratigraphy and biogeography of Cretaceous charophytes from South America: Cretaceous Research, v. 21, p. 211-220.

This article is protected by copyright. All rights reserved 
Paumard, V., Bourget, J., Lang, S., Wilson, T., Riera, R., Gartrell, A., Vakarelov, B.K., O'Leary, M., George, A.D. (2019a). Imaging past depositional environments of the North West Shelf of Australia: lessons from 3D seismic data, in KEEP, M. \& MOSS, S.J. (Eds), The Sedimentary Basins of Western Australia V: Proceedings of the Petroleum Exploration Society of Australia Symposium, Perth, WA, 2019, 30 pp.

Paumard, V., Bourget, J., Payenberg, T., George,A.D., Ainsworth, R.B., Lang, S. (2019b). From quantitative 3D seismic stratigraphy to sequence stratigraphy: Insights into the vertical and lateral variability of shelfmargin depositional systems at different stratigraphic orders. Marine and Petroleum Geology, 110, 797831.

Pazzaglia, F.J., \& Brandon, M.T. (1996). Macrogeomorphic evolution of the post-Triassic Appalachian mountains determined by deconvolution of the offshore basin sedimentary record. Basin Research 8 , 255-278.

Pazzaglia, F.J., \& Gardner, T.W. (1994). Late Cenozoic flexural deformation of the middle U.S. Atlantic passive margin. Journal of Geophysical Research 99, 12143-12157.

Perch-Nielsen, K., Supko, P.R., Boersma, A., Carlson, R.L., Dinkelman, M.G., Fodor, R.V., Kumar, N., McCoy, F., Thiede, J., Zimmerman, H.B. (1977). Site 356: São Paulo Plateau. DSDP Volume XXXIX. doi:10.2973/dsdp.proc.39.105.1977

Pérez-Díaz, L., \& Eagles, G. (2017). South Atlantic paleobathymetry since early Cretaceous. Sci Rep 7, 11819. https://doi.org/10.1038/s41598-017-11959-7

Pérez Panera, J.P., Lovecchio, J.P., Ronchi, D.I., Angelozzi, G.N., Calvo Marcilese, L., Tortora, L., Calaramo, N., Kress Frieling P.R. (2016). Bioestratigrafía y Reconstrucción Paleoambiental de las cuencas del Salado y Punta del Este en el lapso Maastrichtiano - Mioceno. VI Jornadas de Geociencias - “Compartiendo Geociencias, Impulsando Comunidades".

Petter, AL., Steel, RJ., Mohrig, D., Kim, W., Carvajal, C. (2013) Estimation of the paleoflux of terrestrialderived solids across ancient basin margins using the stratigraphic record. GSA Bulletin ; 125 (3-4): 578593. doi: https://doi.org/10.1130/B30603.1

Poag, C.W., \& Sevon, W.D. (1989). A record of Appalachian denudation in post-rift Mesozoic and Cenozoic sedimentary deposits of the U.S. Middle Atlantic continental margin. Geomorphology 2, 119-157.

This article is protected by copyright. All rights reserved 
Ramos, V.A.( 2010). The tectonic regime along the Andes: Present-day and Mesozoic regimes. Geological Journal, vol. 45, p. 2-25.

Ramos, V.A., \& Aleman, A. (2000). Tectonic Evolution of the Andes. In: Cordani, U.G., Milani, E.J., Thomaz Filho, A., Campos, D.A. (eds.) Tectonic evolution of South America, Río de Janerio, pp. 635-685

Razik, S., Govin, A., Chiessi, C.M., Dobeneck, T. (2015). Depositional provinces, dispersal, and origin of terrigenous sediments along the SE South American continental margin. Marine Geology. Volume 363, Pages 261-272. https://doi.org/10.1016/j.margeo.2015.03.001

Reis do Amorin, N. (2013). Caracterização geofísica da dorsal de são paulo e seu significado evolutivo na bacia de Santos. BcS, Universidade Federal Fluminense, 60p.

Repasch, M., Wittmann, H., Scheingross, J. S., Sachse, D., Szupiany, R., Orfeo, O., et al. (2020). Sediment transit time and floodplain storage dynamics in alluvial rivers revealed by meteoric $10 \mathrm{Be}$. Journal of Geophysical Research: Earth Surface, 125, e2019JF005419. https://doi.org/10.1029/2019JF005419

Rohais, S., Bonnet, S., Eschard, R. (2012). Sedimentary record of tectonic and climatic erosional perturbations in an experimental coupled catchment-fan system. Basin Res. 24, 198-212.

https://doi.org/10.1111/j.1365-2117.2011.00520.x.

Rohais, S., Barrois, A., Colletta, B., Moretti, I. (2016). Pre-salt to salt stratigraphic architecture in a rift basin: insights from a basin-scale study of the Gulf of Suez (Egypt). Arab. J. Geosci. 9, 317. https://doi.org/10.1007/s12517-016-2327-8.

Rohais, S., Hamon, Y., Deschamps, R. , Beaumont, V., Gasparrini, M., Pillot, D., Romero-Sarmiento, M. (2019). Patterns of organic carbon enrichment in a lacustrine system across the K-T boundary: insight from a multi-proxy analysis of the Yacoraite Formation, Salta rift basin, Argentina. Journal of Coal Geology. Volume 210, ISSN 0166-5162, https://doi.org/10.1016/j.coal.2019.05.015.

Rohais, S., \& Rouby, D. (2020). Source-to-Sink analysis of the Plio-Quaternary deposits in the Suez rift (Egypt). In S. Khomsi et al. (eds.), Arabian Plate and Surroundings: Geology, Sedimentary Basins and Georesources, Regional Geology Reviews, Pages 115-133, https://doi.org/10.1007/978-3-030-21874-4_4

Romans, B.W., Castelltort, S., Covault, J.A., Fildani, A., Walsh, J.P. (2016). Environmental signal propagation in sedimentary systems across timescales Earth Sci. Rev., 153, pp. 7-29,

10.1016/j.earscirev.2015.07.012

This article is protected by copyright. All rights reserved 
Rosa, M.L., Barboza, E.G., Abreu, V., Tomazelli, L.J., Dillengurg, S.R. (2017). High-Frequency Sequences in the Quaternary of Pelotas Basin (coastal plain): a record of degradational stacking as a function of longerterm base-level fall. Braz. J. Geol., vol.47, n.2, pp.183-207. ISSN 2317-4889.

https://doi.org/10.1590/2317-4889201720160138.

Rouby, D., Braun, J., Robin, C., Dauteuil, O., Deschamps, F. (2013). Long-term stratigraphic evolution of Atlantic-type passive margins: A numerical approach of interactions between surface processes, flexural isostasy and 3D thermal subsidence. Tectonophysics 604, 83-103,

http://dx.doi.org/10.1016/j.tecto.2013.02.003

Rouby, D., Bonnet, S., Guillocheau, F., Gallagher, K., Robin, C., Biancotto, F., Dauteuil, O., Braun, J. (2009). Sediment supply to the Orange sedimentary system over the last150 My: an evaluation from sedimentation/denudation balance. Mar. Petrol. Geol., 26, 782-794

Rust, D.J., \& Summerfield, M.A. (1990). Isopach and borehole data as indicators of rifted margin evolution in southwestern Africa. Marine and Petroleum Geology 7, 277-287.

Saunders, M., \& Bowman, S. (2014). The Pelotas basin oil province revealed - New interpretation from long offset 2D seismic data. First Break, v. 32, p. 67-72

Schumm, S.A., \& Rea, D.K, (1995). Sediment yield from disturbed earth systems. Geology, v. 23, no. 5, p. 391-394

Sébrier, M.,\& Soler, P. (1991). Tectonics and magmatism in the Peruvian Andes from late Oligocene time to the present R.S. Harmon, C.W. Rapela (Eds.), Andean Magmatism and its Tectonic Setting, Geol. Soc. Am. Spec. Pap., 265 (1991), pp. 259-278

Simpson, G., \& Castelltort, S. (2012) Model shows that rivers transmit high-frequency climate cycles to the sedimentary record. Geology 40, 1131-1134. http://dx.doi.org/10.1130/G33451.1.

Soto, M., Morales, E., Veroslavsky, G., de Santa Ana, H., Ucha, N., Rodríguez, P. (2011). The continental margin of Uruguay: crustal architecture and segmentation. Mar. Pet. Geol. 28, 1676-1689.

Stica, J. M., Zalán, P. V., Ferrari, A. L. (2014). The evolution of rifting on the volcanic margin of the Pelotas Basin and the contextualization of the Paraná-Etendeka LIP in the separation of Gondwana in the South Atlantic. Marine and Petroleum Geology, 50, 1-21. https://doi.org/10.1016/j.marpetgeo.2013.10.015 
Syvitski, J.P. \& Milliman, J.D., (2007). Geology, geography, and humans battle for dominance over the delivery of fluvial sediment to the coastal ocean. The Journal of Geology, 115(1), pp.1-19.

Talwani, M., \& Abreu, V., 2000. Inferences regarding initiation of oceanic crust formation from the U.S. east coast margin and conjugate South Atlantic margins. Atl. Rift. Cont. margins. 115, 211-233. https://doi.org/10.1029/GM115p0211

Uenzelmann-Neben, G., Weber, T., Grützner, J., Maik, T. (2017). Transition from the Cretaceous ocean to Cenozoic circulation in the western South Atlantic - a twofold reconstruction. Tectonophysics. http://dx.doi.org/10.1016/j.tecto.2016.05.036.

Vail, P.R., Mitchum, R.M., Thompson, S. (1977). Seismic stratigraphy and global changes of sea level, Part 4: Global cycles of relative changes of sea level, in Payton, C.E. Seismic stratigraphy - applications to hydrocarbon exploration. American Association of Petroleum Geologists Memoir 26, p. 83-133.

Vail, P.R. (1987). Seismic stratigraphic interpretation procedure, in Bally, A.W. Atlas of seismic stratigraphy. American Association of Petroleum Geologists Studies in Geology, v. 27, p. 1-10.

Van Wagoner, J.C., Posamentier, H.W., Mitchum, R.M., Vail, P.R., Sarg, J.F., Loutit, T.S., Hardenbol, J. (1988). An overview of the fundamentals of sequence stratigraphy and key definitions. In: Wilgus, C.K., Hastings, B.S., Kendall, C.G.St.C., Posamentier, H.W., Ross, C.A., Van Wagoner, J.C. (Eds.), Sea Level Changes: An Integrated Approach. SEPM Special Publication, vol. 42, pp. 39-45.

Walford, H., \& White, N.J. (2005). Constraining uplift and denudation of west African continental margin by inversion of stacking velocity data. Journal of Geophysical Research 110, B04403, doi:10.1029/2003JB002893.

Weschenfelder, J., Baitelli, R., Corrêa, I.C.S., Bortolin, E.C., Dos Santos, C.B. (2014). Quaternary incised valleys in southern Brazil coastal zone. Journal of South American Earth Sciences, 55:83-93.

Westerhold, T., \& Röhl, U. (2013). Orbital pacing of Eocene climate during the Middle Eocene Climate Optimum and the chron C19r event: Missing link found in the tropical western Atlantic, Geochem. Geophys. Geosyst., 14, 4811-4825, doi:10.1002/ggge.20293.

Zhang, J., Covault, J., Pyrcz, M., Sharman, G., Carvajal, C. Milliken, K., (2018). Quantifying sediment supply to continental margins: Application to the Paleogene Wilcox Group, Gulf of Mexico. AAPG Bulletin, 102(9), pp.1685-1702.

This article is protected by copyright. All rights reserved 
Zhang, J., Burgess, P.M., Granjeon, D., Steel, R. (2019) Can sediment supply variations create sequences? Insights from stratigraphic forward modelling. Basin Res.; 31: 274-289.

https://doi.org/10.1111/bre.12320

This article is protected by copyright. All rights reserved 


\begin{tabular}{|c|c|c|}
\hline Source & $\begin{array}{l}\text { Data type and } \\
\text { number }\end{array}$ & Name \\
\hline $\begin{array}{l}\text { Nielsen et al. } \\
(1977)\end{array}$ & $\begin{array}{l}\text { Well } \\
(1)\end{array}$ & DSDP Site356 \\
\hline \multirow[t]{2}{*}{ Fontana (1996) } & $\begin{array}{l}\text { 2D seismic line } \\
(20)\end{array}$ & $\begin{array}{l}\text { 043, 045, 046, 047, 048, 049, 050, 052, } \\
\text { 053, 057, 059 (Leplac-IV) } \\
\text { 0228-0313, 0228-0315, 0228-0317, 0228- } \\
0325,0228-0327,0231-0492,0239-0369, \\
0034-0223,0239-0370\end{array}$ \\
\hline & $\begin{array}{l}\text { Well } \\
(5)\end{array}$ & $\begin{array}{l}\text { 1-RSS-0002-RS, 1-RSS-0003-RS, 2-RSS-0001- } \\
\text { RS, 1-SCS-0003B-SC, 1-SCS-0002-SC }\end{array}$ \\
\hline \multirow[t]{2}{*}{ Abreu (1998) } & $\begin{array}{l}\text { 2D seismic line } \\
\text { (5) }\end{array}$ & $\begin{array}{l}\text { PA (0228-0315), PB (0228-0317), PC (0228- } \\
0326, \mathrm{D} 1), \mathrm{PD}(0228-0327, \mathrm{D} 3), \mathrm{PE}(0231- \\
0492)\end{array}$ \\
\hline & $\begin{array}{l}\text { Well } \\
(4)\end{array}$ & $\begin{array}{l}\text { P1 (1-RSS-0002-RS), P2 (2-RSS-0001-RS), } \\
\text { P3 (1-SCS-0003B-SC), P4 (1-SCS-0002-SC) }\end{array}$ \\
\hline $\begin{array}{l}\text { Bassetto et al. } \\
(2000)\end{array}$ & $\begin{array}{l}\text { 2D seismic line } \\
\text { (4) }\end{array}$ & 059-059A, 043, 047, 048 (Leplac-IV) \\
\hline Correa (2004) & $\begin{array}{l}\text { 2D seismic line } \\
\text { (4) }\end{array}$ & 059-059A, 047, 050, 053 (Leplac-IV) \\
\hline \multirow[t]{2}{*}{ Machado (2010) } & $\begin{array}{l}\text { 2D seismic line } \\
\text { (9) }\end{array}$ & $\begin{array}{l}\text { 0248-0106, 0231-0498, 0228-0322 (S1), } \\
0044-0153 \text { (S2), 0228-0326 (PC, D1), 0231- } \\
0477,0034-0219,0231-1355,0034-0223\end{array}$ \\
\hline & $\begin{array}{l}\text { Well } \\
(2)\end{array}$ & 1-SCS-0003B-SC (P3), 1-SCS-0002-SC (P4) \\
\hline \multirow[t]{2}{*}{$\begin{array}{l}\text { Contreras et al. } \\
\text { (2010) }\end{array}$} & $\begin{array}{l}\text { 2D seismic line } \\
\text { (1) }\end{array}$ & 0239-0370 (their figure 7) \\
\hline & $\begin{array}{l}\text { Well } \\
(1)\end{array}$ & 1-BPS-008-BP \\
\hline Cardozo (2011) & $\begin{array}{l}\text { 2D seismic line } \\
(25)\end{array}$ & $\begin{array}{l}\text { 0034-0001, 0034-0002, 0034-0005, 0231- } \\
\text { 0492, 0034-0004, 0228-0322, 0231-0492 } \\
\text { (PE), 0044-0153, 0048-0041, 0239-0368, } \\
\text { 0231-1356, 0231-0486, 0231-0498, 0228- } \\
\text { 0321, 0231-1343, 0228-0317 (Fontana, } \\
\text { 1996, PB), 0231-1346, 0228-0311, 0239- } \\
\text { 0370, 0228-0315, 0228-0327 (PD), 0231- } \\
\text { 1355, 0239-0369, 0231-1351 }\end{array}$ \\
\hline
\end{tabular}




\begin{tabular}{|c|c|c|}
\hline Cruz (2011) & $\begin{array}{l}\text { 2D seismic line } \\
\text { (8) }\end{array}$ & $\begin{array}{l}\text { S1 (0228-0322), S2 (0044-0153), D1 (PC), } \\
\text { D2, D3 (0228-0327, PD), D4, D5, D6 }\end{array}$ \\
\hline Garcia (2012) & $\begin{array}{l}\text { 2D seismic line } \\
\text { (15) }\end{array}$ & $\begin{array}{l}0231-1346,0228-0326,0231-1351,0228- \\
0327 \text { (PD), 0231-0498, 0228-0322, 0231- } \\
0486,0228-317,0231-1355,0231-1356 \\
0239-0369,0048-0041,0034-0225,0048- \\
0454,0231-1360\end{array}$ \\
\hline \multirow[t]{2}{*}{ Morales (2013) } & $\begin{array}{l}\text { 2D seismic line } \\
\text { (6) }\end{array}$ & $\mathrm{d} 1, \mathrm{~d} 2, \mathrm{~d} 3, \mathrm{~s} 1, \mathrm{~s} 2$, Composite \\
\hline & $\begin{array}{l}\text { Well } \\
(2) \\
\end{array}$ & Lobo-1, Gaviotín-1 \\
\hline $\begin{array}{l}\text { Lopes da Silva } \\
\text { (2013) }\end{array}$ & $\begin{array}{l}\text { 2D seismic line } \\
\text { (1) }\end{array}$ & 059-059A (Leplac-IV) \\
\hline $\begin{array}{l}\text { Reis de Amorin } \\
(2013) \\
\end{array}$ & $\begin{array}{l}\text { 2D seismic line } \\
\text { (5) }\end{array}$ & 046, 045, 044, 0511, 059A (Leplac-IV) \\
\hline Stica et al. (2014) & $\begin{array}{l}\text { 2D seismic line } \\
(2)\end{array}$ & their figures 5, 6 \\
\hline Horn (2015) & $\begin{array}{l}\text { 2D seismic line } \\
(4)\end{array}$ & its figures $8,10 a, 10 b, 12$ \\
\hline $\begin{array}{l}\text { Conti (2015), } \\
\text { Conti et al. (2017) }\end{array}$ & $\begin{array}{l}\text { 2D seismic line } \\
\text { (2) }\end{array}$ & their figures 38,41 \\
\hline $\begin{array}{l}\text { Creaser et al. } \\
\text { (2017) }\end{array}$ & $\begin{array}{l}\text { 2D seismic line } \\
\text { (1) }\end{array}$ & their figure 2 \\
\hline
\end{tabular}




\begin{tabular}{|c|c|c|c|c|c|c|c|c|}
\hline \multirow{2}{*}{$\begin{array}{c}\text { Surface } \\
\text { (Abreu, 1998) }\end{array}$} & \multirow{2}{*}{$\begin{array}{c}\text { Age (Ma, } \\
\text { Abreu, 1998) }\end{array}$} & \multirow{2}{*}{$\begin{array}{c}\text { Cycle Chart } \\
\text { (Abreu, 1998) }\end{array}$} & \multirow{2}{*}{$\begin{array}{c}\text { Age (Ma, Rosa } \\
\text { et al., 2017) }\end{array}$} & \multicolumn{2}{|c|}{ This work } & \multirow{2}{*}{$\begin{array}{l}\text { Cycle } \\
\text { duration } \\
\text { (Myr) }\end{array}$} & \multirow[t]{2}{*}{ Large-scale envelops } & \multirow{2}{*}{\begin{tabular}{|r}
$\begin{array}{l}\text { Time/Depth } \\
\text { conversion }\end{array}$ \\
$(\mathrm{m} / \mathrm{sec})$ \\
\end{tabular}} \\
\hline & & & & Cycle chart & $\mathrm{Ma}$ & & & \\
\hline Sea bed 44 & 0 & & 0 & & 0 & & X-Plio-Quaternary & 909 \\
\hline 43 & 0.5 & lo-2 & 0.32 & & 0.44 & 0.44 & & \\
\hline 42 & 0.8 & lo-1 & 0.74 & & 0.64 & 0.2 & & 750 \\
\hline 41 & 1 & MIS22 & 0.92 & & 0.86 & 0.22 & & \\
\hline 40 & 1.2 & Cala-1 = MIS58 & 1.16 & & 1.65 & 0.79 & & 633 \\
\hline $39 c$ & 2 & Gel-2 & 2.08 & & 2.16 & 0.51 & & \\
\hline $39 \mathrm{~b}$ & 2.5 & Gel-1/Pia-2 & 2.54 & & 2.8 & 0.64 & & \\
\hline 39 a & 3 & Pia-1 & 3.06 & & 3.27 & 0.47 & & \\
\hline 39 & 3.7 & Za-2 & 3.48 & Za-1 & 4.62 & 1.35 & & 1077 \\
\hline 38 & 5.8 & $\mathrm{Me}-2$ & 5.46 & Me-2 & 5.77 & 1.15 & IX-Uppermost Miocene & \\
\hline 37 & 6.6 & Me-1 & 6.46 & Me-1 & 7.26 & 1.49 & & 966 \\
\hline $36 \mathrm{a}$ & 8 & & 8.14 & & 8.5 & 1.24 & VIII-Upper Miocene & \\
\hline 36 & 9.4 & Tor-2 & 9.06 & Tor-2 & 9.22 & 0.72 & & \\
\hline $35 \mathrm{~b}$ & 9.8 & & 9.38 & & 10 & 0.78 & & \\
\hline 35 a & 10.2 & & 9.98 & & 10.9 & 0.9 & & \\
\hline 35 & 10.6 & Tor-1 & 10.68 & Tor-1 & 11.8 & 0.9 & & 908 \\
\hline 34 & 12.7 & Ser-3 & 12.1 & Ser-3 & 12.72 & 0.92 & & \\
\hline 33 & 12.8 & & 12.7 & & 12.85 & 0.13 & VII-Middle Miocene & 906 \\
\hline $32 \mathrm{a}$ & 12.9 & & 12.8 & & 13 & 0.15 & & \\
\hline 32 & 13 & & 13.1 & & 13.1 & 0.10 & & \\
\hline 31 & 13.2 & & 13.48 & & 13.4 & 0.30 & & \\
\hline 30 & 14.4 & Ser-1 & 14.24 & Ser-1 & 13.82 & 0.42 & & 949 \\
\hline 29 & 15.2 & Lan-1 & 15.28 & & 14.8 & 0.98 & VI-Lower Miocene & 921 \\
\hline 28 & 15.9 & & 16.12 & & 15.8 & 1.00 & & \\
\hline 27 & 16.1 & & 16.78 & & 16.7 & 0.90 & & \\
\hline 26 & 16.4 & Bur-4 & 18.02 & & 17.54 & 0.84 & & 1333 \\
\hline 25 & 18.3 & Bur-3 & 18.3 & & 18.12 & 0.58 & & 1375 \\
\hline 24 & 19 & Bur-2 & 19.02 & & 19.17 & 1.05 & & 1204 \\
\hline 23 & 23.8 & Bur-1 & 23.7 & & 20.43 & 1.26 & & 1056 \\
\hline $22-23$ & 25.5 & & 25.78 & MFS Aq-1 & 22.24 & 1.81 & & \\
\hline 22 & 27 & Aq-1 & 27.02 & Aq-1 & 23.03 & 0.79 & & 1239 \\
\hline 21 & 28.6 & Ch-2 & 28.58 & & 27.5 & 4.47 & V-Upper Oligocene & 2917 \\
\hline 20 & 30.8 & Ch-1 & 30.76 & & 28.09 & 0.59 & & \\
\hline 19 & 31.5 & Ru-3 & 31.54 & & 29.18 & 1.09 & & 1682 \\
\hline 18 & 32.3 & Ru-2 & 32.42 & & 32.1 & 2.92 & IV-Lower Oligocene & \\
\hline 17 & 33.6 & Ru-1 & 33.8 & Ru-1 & 33.89 & 1.79 & & 1500 \\
\hline $16-17$ & & & 35.4 & MFS Pr-2 or Pr-3 & 35.99 & 2.1 & III- Middle and Upper & \\
\hline 16 & 36.1 & Pr-2 & 36.36 & $\operatorname{Pr}-2$ or $\operatorname{Pr}-3$ & 36.97 & 0.98 & Eocene & 1619 \\
\hline 15 & 41.9 & Pr-1 & 41.9 & Pr-1 & 37.75 & 0.78 & & 1420 \\
\hline 14 & 47.2 & $Y p-10$ & 47.52 & Lu-1 & 47.33 & 9.58 & & 1491 \\
\hline 13 & 65 & Da-1 & 65.02 & Yp-1 & 55.4 & 8.07 & II-Lower Eocene & 1444 \\
\hline 12 & 67.5 & Cam-10 & 67.98 & Da-1 & 65.76 & 10.36 & I-Paleocene & 1596 \\
\hline
\end{tabular}




\begin{tabular}{|c|c|c|c|c|c|c|c|c|c|}
\hline \multirow{2}{*}{$\begin{array}{l}\text { Large-scale } \\
\text { Envelops }\end{array}$} & \multirow{2}{*}{\begin{tabular}{|c|} 
RPC 3D \\
proportion \\
Large-scale \\
Envelops \\
$(\%)$ \\
\end{tabular}} & \multicolumn{2}{|c|}{$\begin{array}{l}\text { RPC 2D proportion of X- } \\
\text { section 0228-327 - Large- } \\
\text { scale Envelops }\end{array}$} & \multicolumn{2}{|c|}{$\begin{array}{c}\text { RPC 2D proportion of X- } \\
\text { section PB - Large-scale } \\
\text { Envelops }\end{array}$} & \multicolumn{2}{|c|}{\begin{tabular}{|c|} 
RPC 2D proportion of X- \\
section Contreras - Large- \\
scale Envelops
\end{tabular}} & \multicolumn{2}{|c|}{$\begin{array}{c}\text { RPC 2D proportion of X- } \\
\text { section Conti - Large-scale } \\
\text { Envelops }\end{array}$} \\
\hline & & $\%$ RPC & $\begin{array}{l}\text { Correction } \\
\text { Factor (CF) }\end{array}$ & \% RPC & $\begin{array}{l}\text { Correction } \\
\text { Factor (CF) }\end{array}$ & \% RPC & $\begin{array}{l}\text { Correction } \\
\text { Factor (CF) }\end{array}$ & $\%$ RPC & $\begin{array}{l}\text { Correction } \\
\text { Factor (CF) }\end{array}$ \\
\hline $\begin{array}{l}\text { X-Plio- } \\
\text { Quaternary }\end{array}$ & $14.0 \%$ & $15.3 \%$ & 0.9 & $8.2 \%$ & 1.7 & $8.8 \%$ & 1.6 & $3.6 \%$ & 3.9 \\
\hline $\begin{array}{l}\text { IX-Uppermost } \\
\text { Miocene }\end{array}$ & $8.7 \%$ & $5.3 \%$ & 1.7 & $7.7 \%$ & 1.1 & $4.1 \%$ & 2.1 & $16.1 \%$ & 0.5 \\
\hline $\begin{array}{l}\text { VIII-Upper } \\
\text { Miocene }\end{array}$ & $10.7 \%$ & $15.1 \%$ & 0.7 & $20.1 \%$ & 0.5 & $7.4 \%$ & 1.5 & $15.1 \%$ & 0.7 \\
\hline $\begin{array}{l}\text { VII-Middle } \\
\text { Miocene }\end{array}$ & $13.4 \%$ & $17.5 \%$ & 0.8 & $7.5 \%$ & 1.8 & $12.1 \%$ & 1.1 & $7.0 \%$ & 1.9 \\
\hline $\begin{array}{l}\text { VI-Lower } \\
\text { Miocene }\end{array}$ & $9.6 \%$ & $15.5 \%$ & 0.6 & $12.2 \%$ & 0.8 & $13.9 \%$ & 0.7 & $12.6 \%$ & 0.8 \\
\hline $\begin{array}{l}\text { V-Upper } \\
\text { Oligocene }\end{array}$ & $9.4 \%$ & $7.3 \%$ & 1.3 & $12.2 \%$ & 0.8 & $9.5 \%$ & 1.0 & $19.0 \%$ & 0.5 \\
\hline $\begin{array}{l}\text { IV-Lower } \\
\text { Oligocene }\end{array}$ & $9.4 \%$ & $7.2 \%$ & 1.3 & $10.1 \%$ & 0.9 & $10.4 \%$ & 0.9 & $4.0 \%$ & 2.4 \\
\hline $\begin{array}{l}\text { III- Middle } \\
\text { and Upper } \\
\text { Eocene }\end{array}$ & $9.8 \%$ & $8.5 \%$ & 1.2 & $8.0 \%$ & 1.2 & $14.1 \%$ & 0.7 & $5.9 \%$ & 1.7 \\
\hline $\begin{array}{l}\text { II-Lower } \\
\text { Eocene }\end{array}$ & $6.5 \%$ & $4.7 \%$ & 1.4 & $7.4 \%$ & 0.9 & $8.1 \%$ & 0.8 & $10.3 \%$ & 0.6 \\
\hline I-Paleocene & $8.4 \%$ & $3.7 \%$ & 2.3 & $6.7 \%$ & 1.3 & $11.4 \%$ & 0.7 & $6.3 \%$ & 1.3 \\
\hline
\end{tabular}




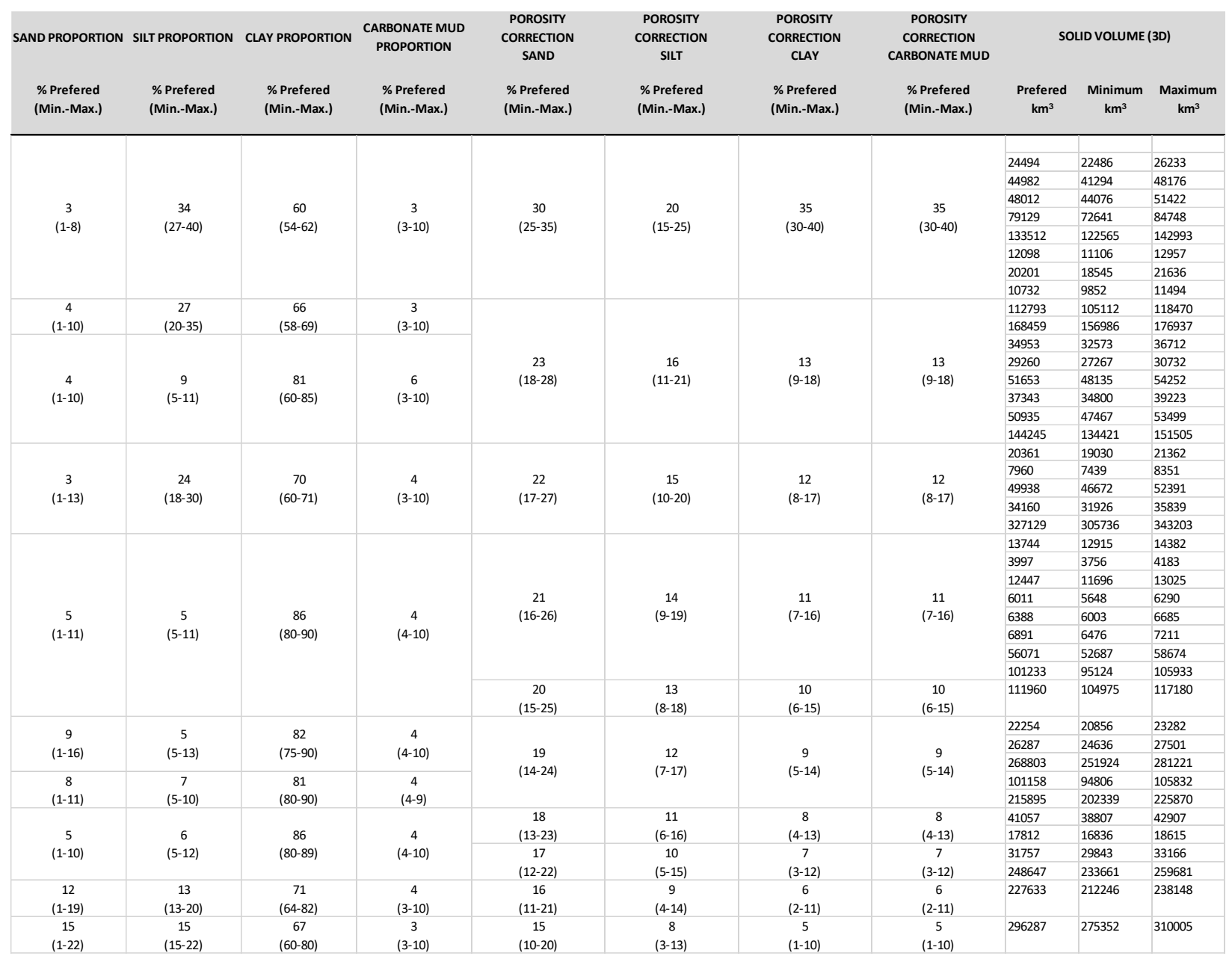


Duration Unit

Forcings and their periods

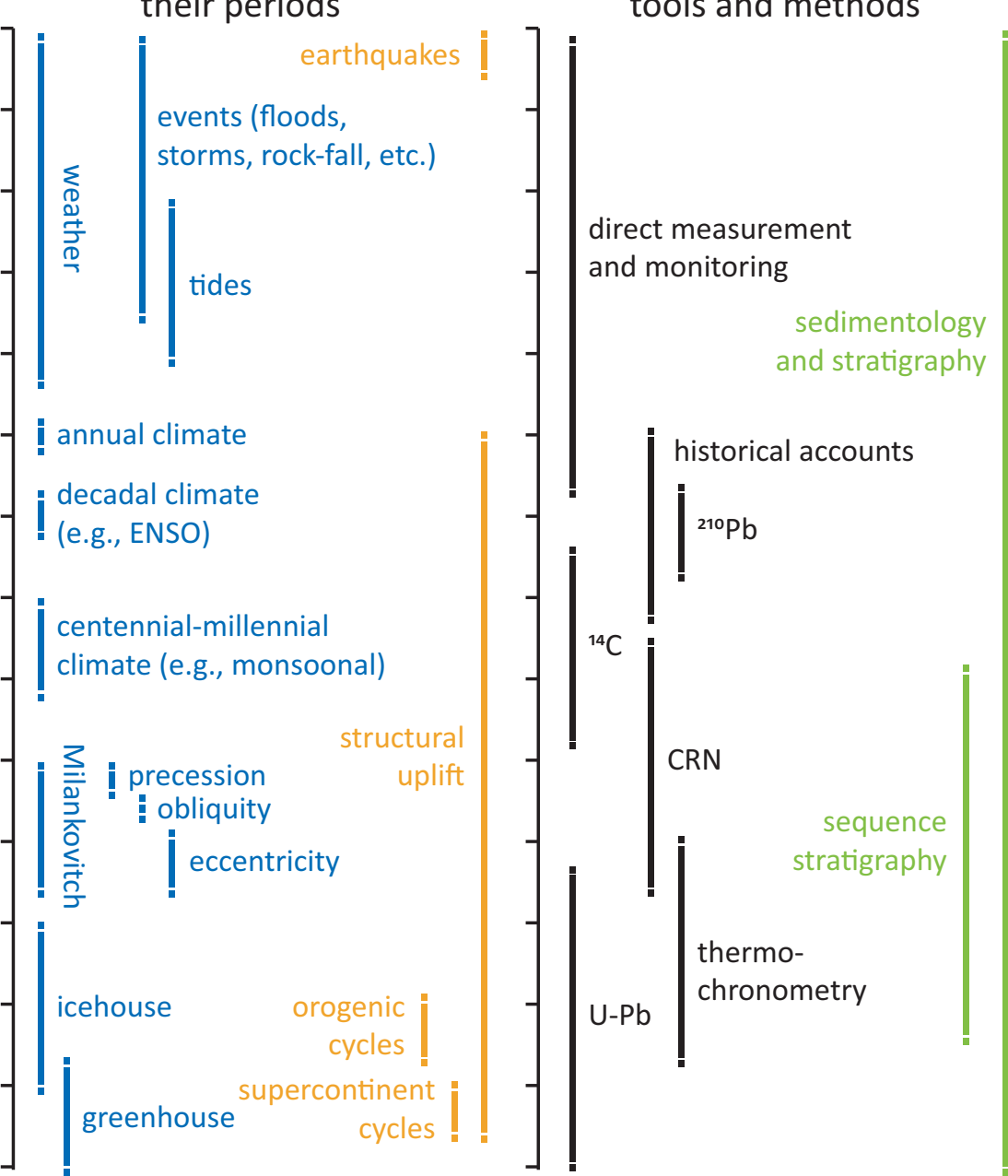

Chronometric

$10^{-5}$

$10^{-4}$

minutes

$10^{-3}$

$10^{-2}$

$10^{-1}$

months

$10^{0}$

$10^{1}$

$10^{2}$

$10^{3}$

$10^{4}$

$10^{5}$

$10^{6}$

$10^{7}$

$10^{8}$

$10^{9}$ tools and methods 


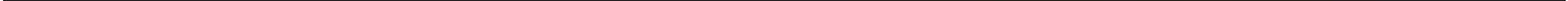




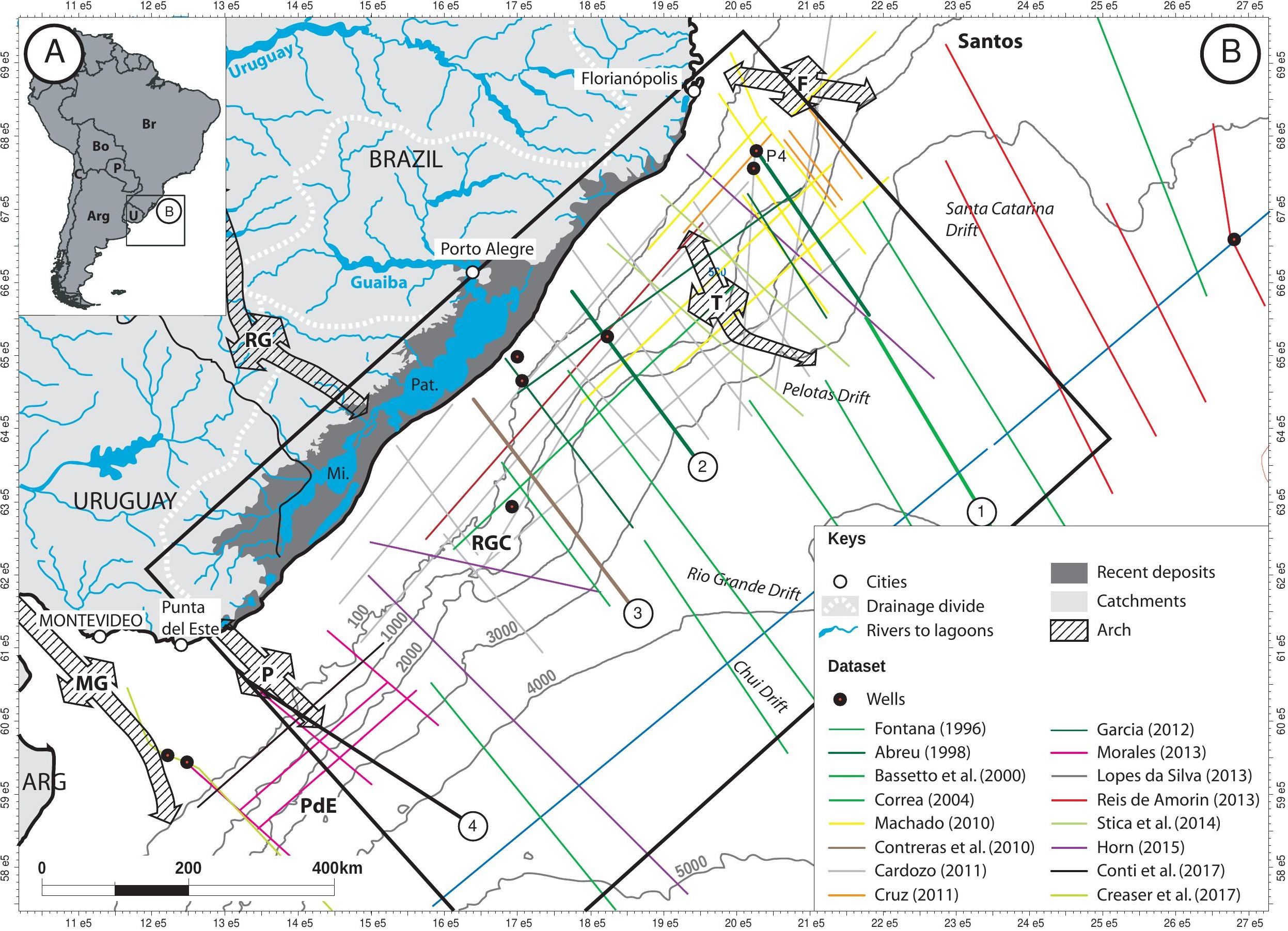


Basin-scale characterization
Seismic sequence stratigraphy
Sediment supply estimation
3D sedimentary budget
OBJECTIVE:

To establish the largescale stratigraphic architecture
OBJECTIVE:

To select a representative 2D dip section

\section{OBJECTIVE:} To establish highresolution (HR) sequence stratigraphic framework
OBJECTIVE:

To correct from in-situ sediment production and define solid volumes
OBJECTIVE:

To restore 3D sedimentary budget with associated uncertainties
1. Multi 2D sections interpretation (main markers)

2. Interpolation and large-scale depositional units

3. Age model
1. Representative Proportion Curve (RPC) in 2D (Multi sections)

2. Reference section selection including Time/Depth uncertainty (Correction Factor)
1. HR seismic sequence stratigraphy on reference section

2. HR age model and Well tie

3. HR Representative Proportion Curve (RPC-HR)
1. Lithology correction (sediment supply versus in-situ production)

2. Porosity correction
1. RPC-HR combined with large-scale depositional units

2. Uncertainty (timeto-depth, age model, lithology and porosity) 


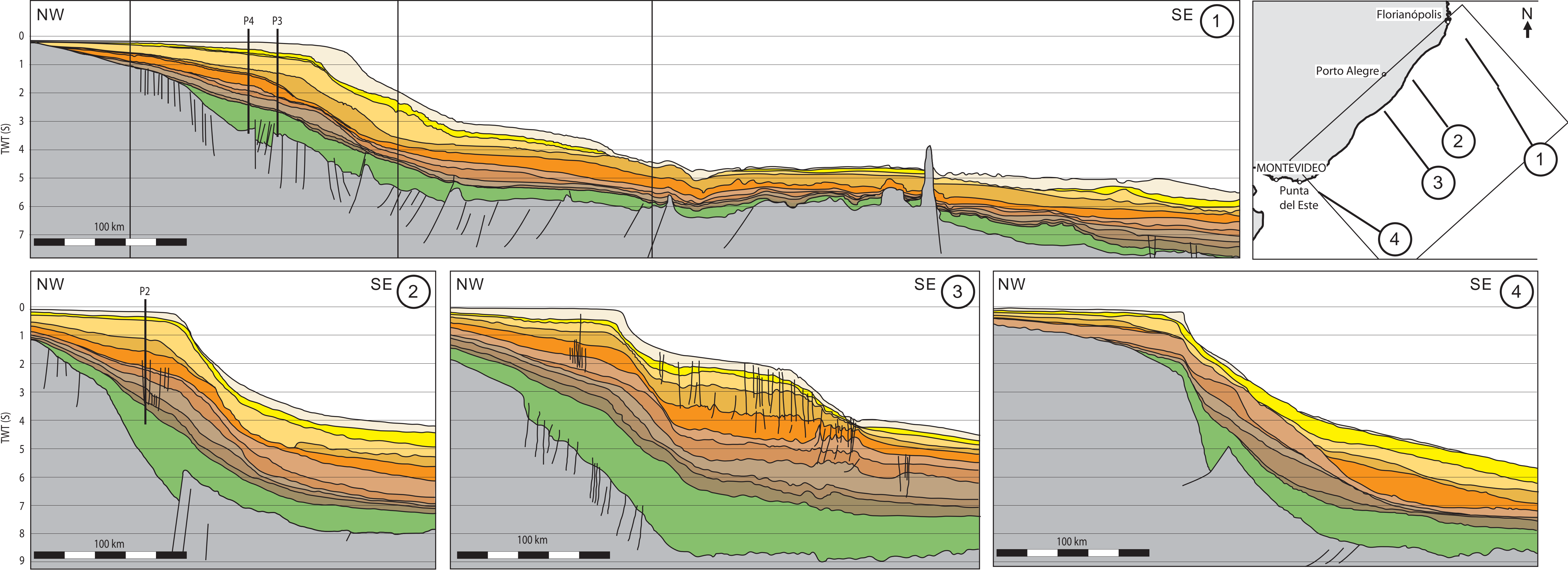

X-Plio-Quaternary

IX-Uppermost Miocene

VIII-Upper Miocene
VII-Middle Miocene

VI-Lower Miocene

V-Upper Oligocene
IV-Lower Oligocene

III-Mid- to Upper Eocene

II-Lower Eocene
I-Paleocene

Cretaceous (undifferentiated)

Basement 
IV-Lower

Oligocene

II-Lower

Eocene
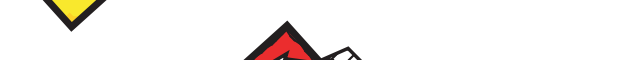

Upper Eocene

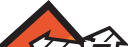




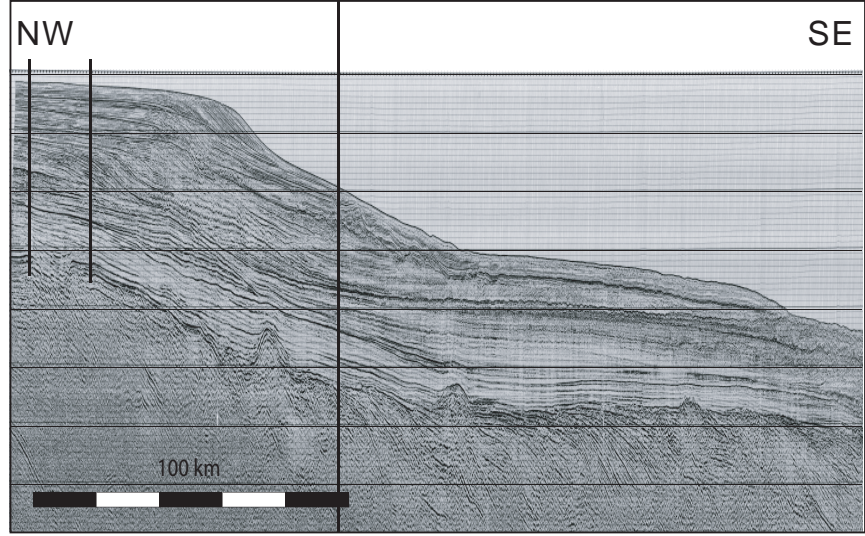

IX-Uppermost Miocene

VIII-Upper Miocene

VII-Middle Miocene

VI-Lower Miocene

V-Upper Oligocene
III-Mid- to Upper Eocene

II-Lower Eocene

I-Paleocene

Cretaceous undifferentiated Basement

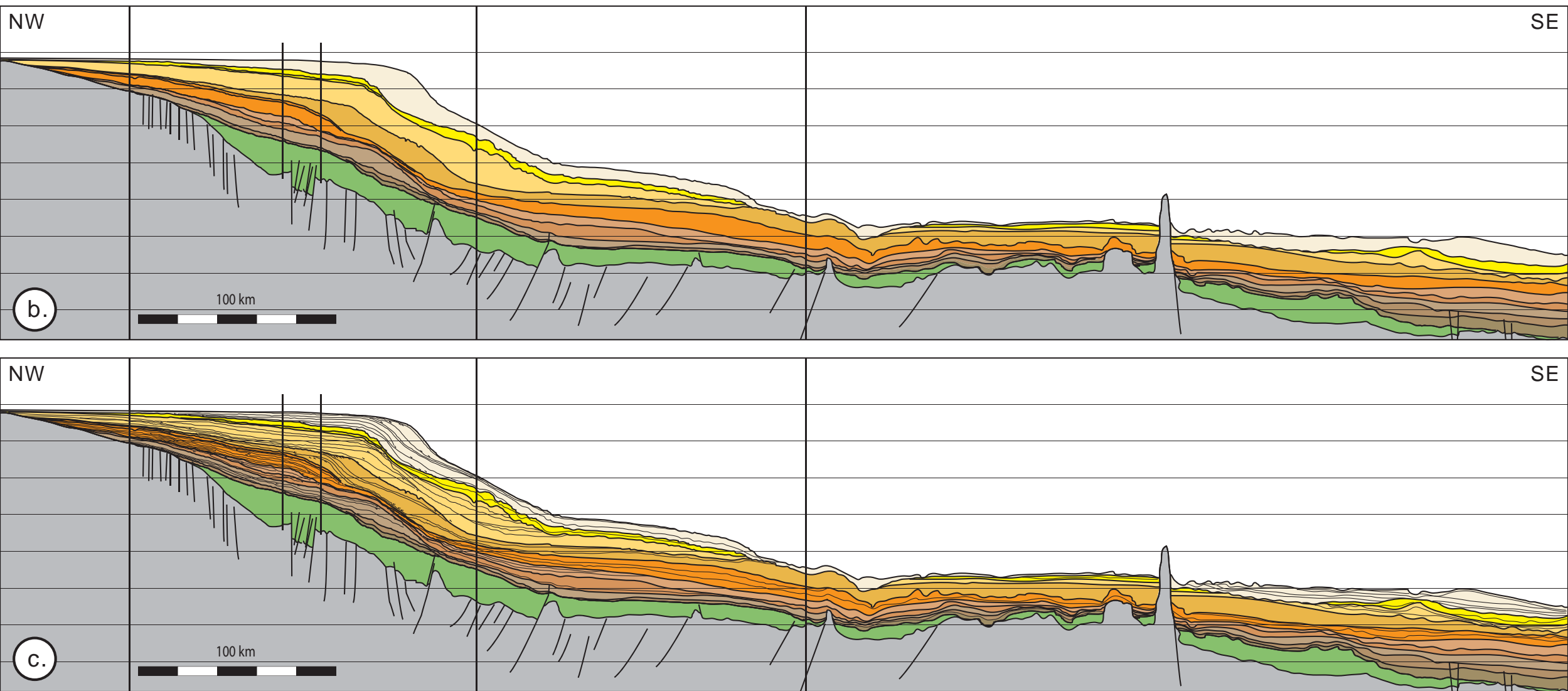


A. RPC 3D proportion (\%)
Large-scale depositional unit

B. RPC 2D proportion (\%)

Large-scale depositional units

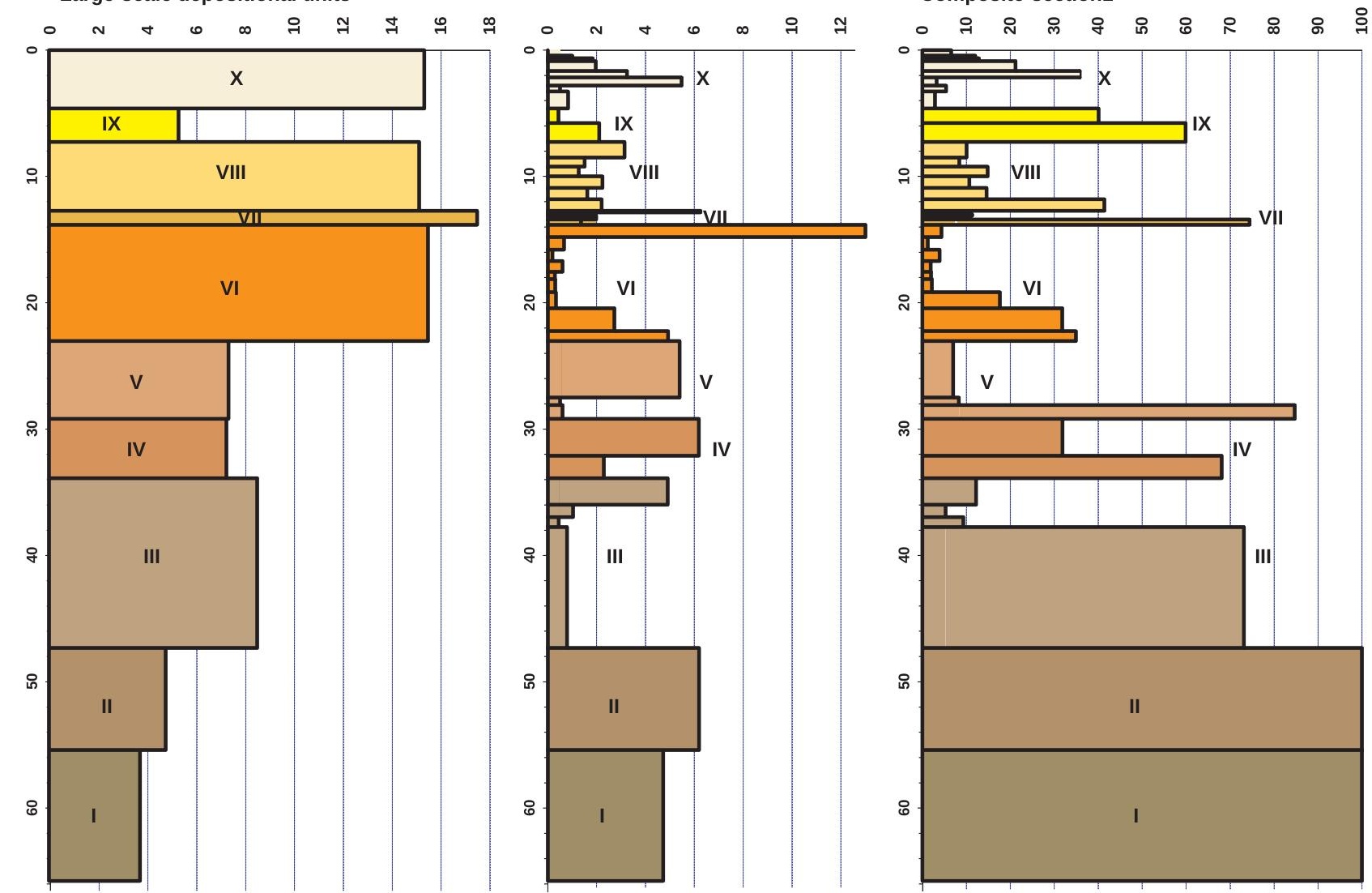


A. Total supply Qs
Large-scale Envelopes

Uncorrected from

porosity and lithology

(km³/Myr) $\begin{array}{llll}\text { B. Total supply Qs (RPS-HR 2D proportion) } & \text { C. Relative } & \text { D. Relative } & \text { E. Relative } \\ \text { Correction Factor (CF) apply } & \text { proportion: } & \text { proportion: } & \text { proportion: } \\ \text { Uncorrected from } & \text { Sand (\%) } & \text { Silt }(\%) & \text { Clay (\%) }\end{array}$

porosity and lithology

(km³/Myr)

F. Relative
proportion

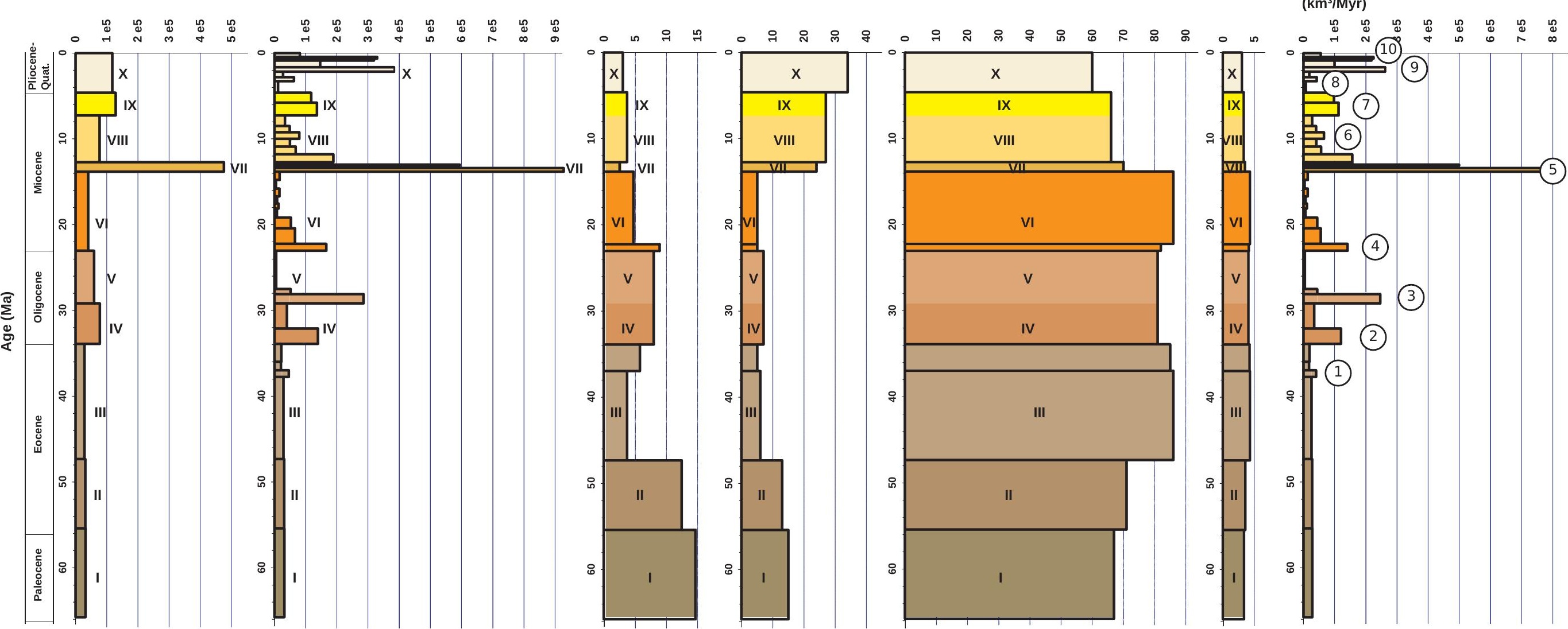


A. Time-to-depth sensitivity

Qs (km³/Myr)
B. Age model sensitivity

$$
\text { Qs (km³/Myr) }
$$

C. Porosity and lithology sensitivity

\section{Qs (km³/Myr)}

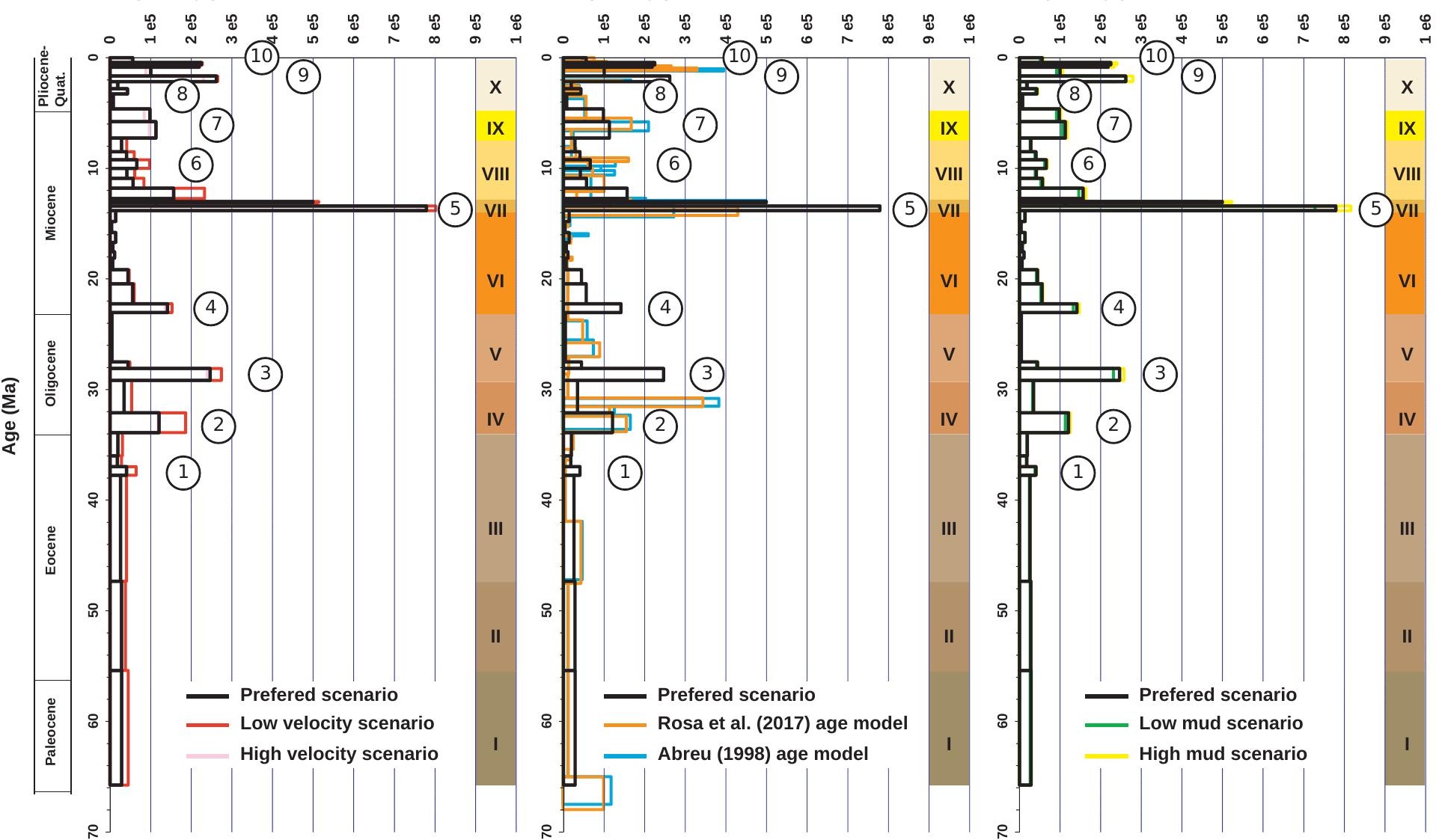




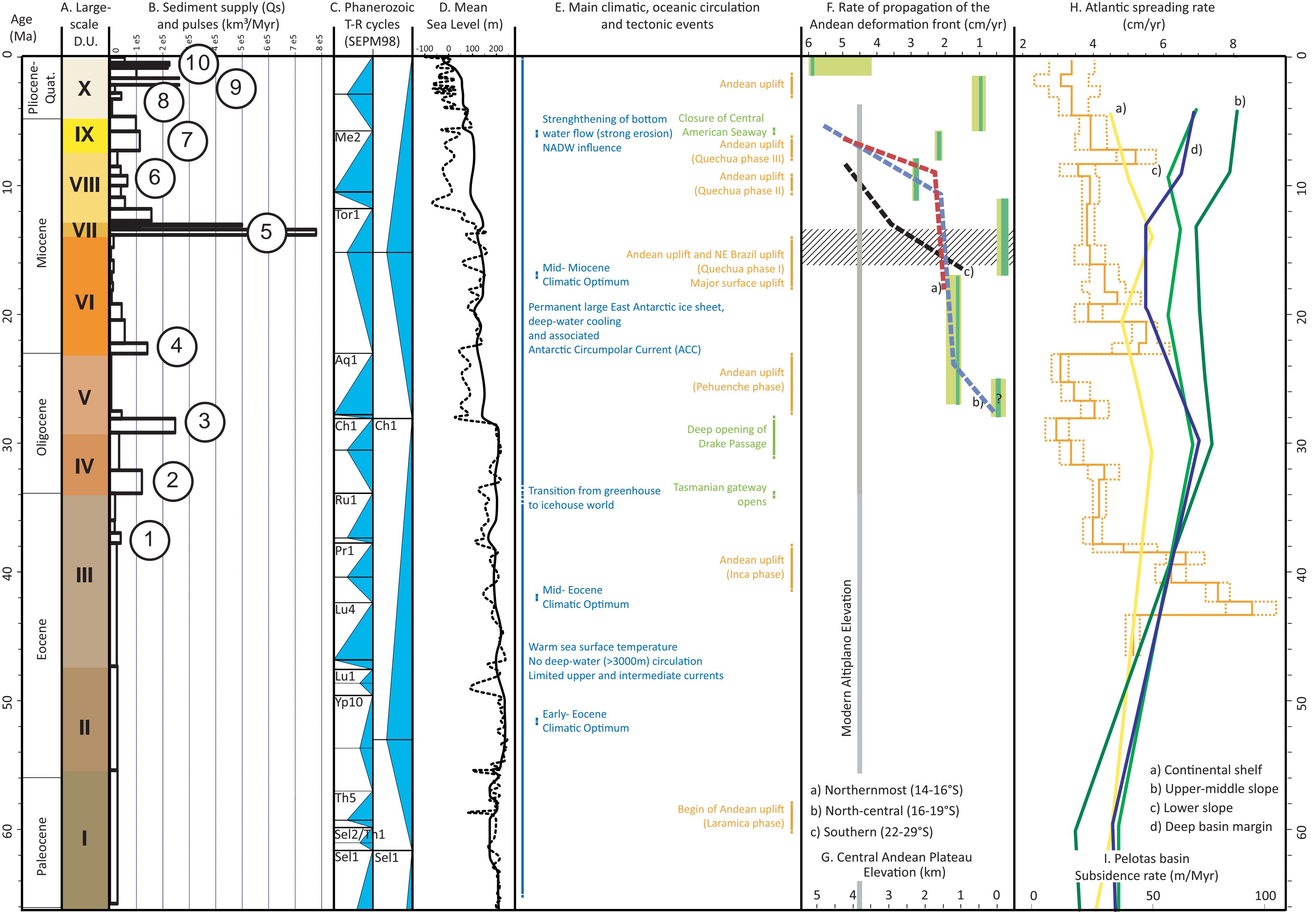

